\title{
Leaving Home, Bastion of the Spectacular Rifā̄īs
}

The site of Wāsit in modern-day Iraq hardly shows any trace of the city's former glory. According to legend, the city's location was chosen by its founder, the Umayyad governor al-Ḥajjāj b. Yūsuf (d. 95/714), after a Christian monk claimed to have read in divine scripture that there would be a mosque there that would not cease to exist as long as there remains anyone who professes God's oneness. ${ }^{1}$ Alas, this prediction did not prove to be true, for the city was abandoned around the middle of the ninth/fifteenth century after having suffered several sieges. This was followed by a gradual change in the course of the Tigris River, which turned further and further east, leaving the city, which had once lain directly on its right bank, in a barren desert. Thus, by the eleventh/ seventeenth century there was nothing left of the fertile grounds, gardens, reeds, and date palms that had characterized Wāsiț, and the city had become a ghost town in ruin. ${ }^{2}$

However, Wāsit was still a flourishing city in the seventh/thirteenth century, even after it was conquered by the Mongols. A century before that, after a long period of strife, the political and religious policy of the thirty-fourth 'Abbāsid caliph, al-Nāșir li-Dīn Allāh (r. 575-622/118o-1225), ensured that the caliphate of Iraq was able to expand and solidify, which brought a period of peace, prosperity, and expansion for Wāsit as a center of Sunni Islam as well. ${ }^{3}$ This policy

1 For the full story, see Muhammad Ibn Jarīr al-Ṭabarī, The History of al-Ṭabarī. Volume XXIII. The Zenith of the Marwānid House, trans. Martin Hinds (Albany, N.Y.: State University of New York Press, 1990), p. 71.

2 C. Edmund Bosworth, "Wāsiț: the rise and disappearance of a great Islamic city," in GraecoArabica: Festschrift in Honour of V. Christides, ed. George K. Livadas (Athens: IGOAS, 2004), pp. 87-88; Mondher Sakly, and Robert Darley-Doran, "Wasit (Wāsiț)," in Historic Cities of the Islamic World, ed. C. Edmund Bosworth (Leiden / Boston: E.J. Brill, 2007), p. 551; Guy LeStrange, The Lands of the Eastern Caliphate: Mesopotamia, Persia, and Central Asia from the Moslem Conquest to the Time of Timur (Cambridge: Cambridge University Press, 1905), pp. 39-40.

3 For a study on al-Nāṣir, see Angelika Hartmann, An-Nāṣir li-Dīn Allāh, 1180-1225: Politik, Religion, Kultur in der späten 'Abbāsidenzeit (Berlin: Walter de Gruyter, 1975), chapter 3 in particular. For a more recent study that gives a good overview of al-Nāșir's politics, see Erik S. Ohlander, Sufism in an Age of Transition: 'Umar al-Suhrawardī and the Rise of the Islamic Mystical Brotherhoods (Leiden: Brill, 2008), pp. 16-27; Bosworth, "Wāsiț," p. 84; Sakly and Darley-Doran, "Wasit (Wāsiț)," p. 553. 


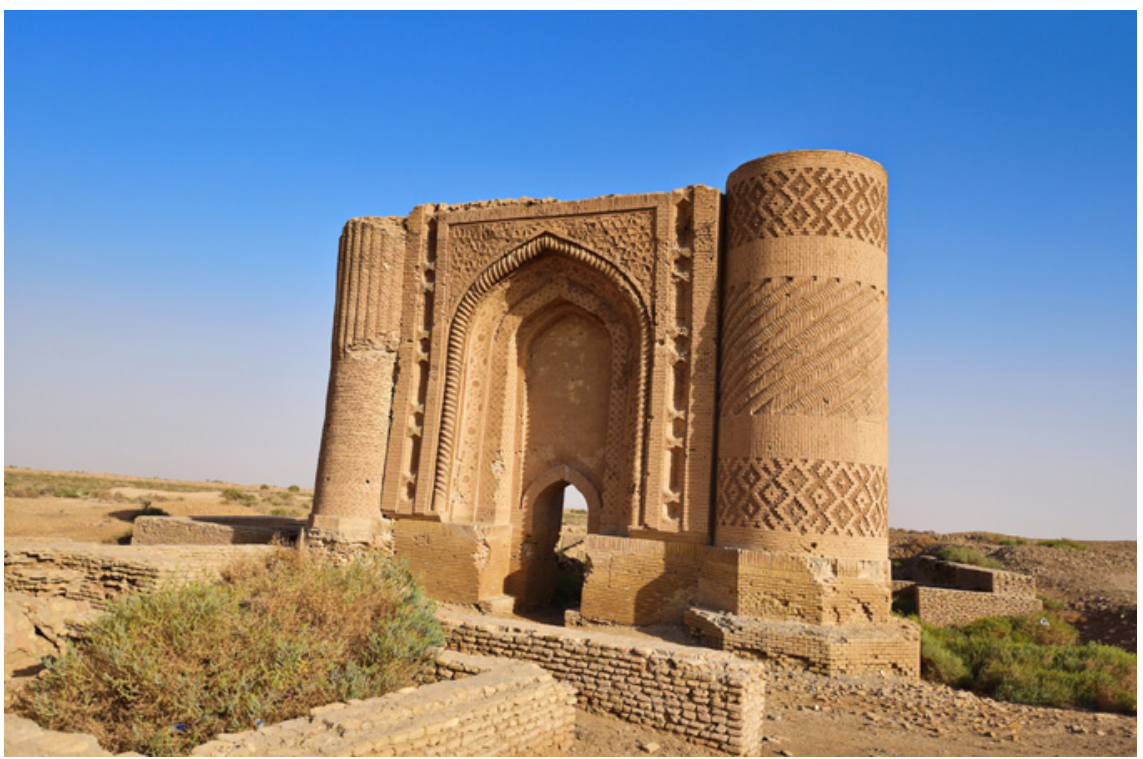

FIGURE 2 The front of one of Wāsiț's gates.

(C) AHMAD MAHDI SALIH

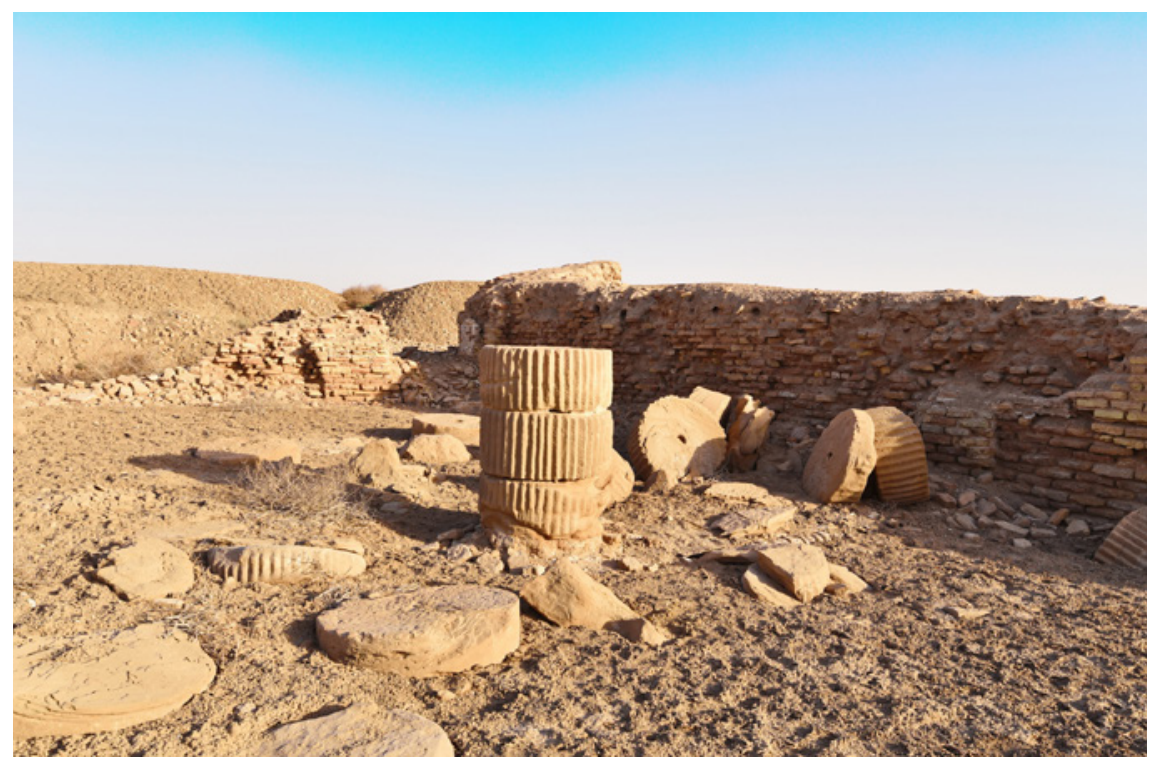

FIGURE 3 Remains of Wāsiṭ.

(c) AHMAD MAHDI SALIH 
was continued up till the caliph al-Mustanșir bi-Allāh (r. 623-640/1226-1242) but ended violently with the Mongols' execution of the latter's son and successor, al-Musta'șim bi-Allāh (r. 640-656/1242-1258), who would go into history as the last caliph of Baghdad. ${ }^{4}$ On 4 Șafar 656/10 February 1258, Baghdad fell before the military strength of Hülagü's Mongol troops. He had been sent westwards into Persia by his brother Möngke Khan, the third Khan after his grandfather Čingiz, with the order to expand the empire. From the lands Hülagü conquered he soon raised his own Mongol dynasty known as the Ilkhanate, which remained in power for almost a century. After Baghdad, Hülagü sent two of his generals, Köke-Ilge and Qara Boghā, to conquer the rest of Mesopotamia. A few months later in Rabī' I/April of the same year, they took Wāsiț, which reportedly cost the city 40,000 lives, and devastated its quarter on the opposite east side of the Tigris. ${ }^{5}$

It would be almost two years after the supposed massacre of Wāsit that 'Imād al-Dīn Aḥmad al-Wāsiṭi was born in this very city, on either 11 or 12 Dhū al-Hijja 657, corresponding to 29 or 3 o November 1259.6 It is likely that he grew up in Hazzāmūn, a large quarter (mahalla) in the east of Wāsiț, as several sources mention he was known as Ibn shaykh al-Hazzämiyyin: the son of the shaykh of Ḥazzāmūn's inhabitants. ${ }^{7}$ His father, Ibrāhīm b. 'Abd al-Raḥmān b.

4 Marshall G. S. Hodgson, The Venture of Islam, Volume 2: the Expansion of Islam in the Middle Periods (University of Chicago Press, 1977), p. 285; Henri Laoust, "Le Hanbalisme sous le califat de Bagdad (241/855-656/1258)." REI I (1959): pp. 117-118.

5 This quarter had once been a separate pre-Islamic town by the name of Kaskar; see: Bertold Spuler, Die Mongolen in Iran: Politik, Verwaltung und Kultur der Ilchanzeit 1220-1350 (Leiden: E.J. Brill, 1985), pp. 46-50; Bosworth, "Wāsiț," pp. 85-86.

6 Cf. Shams al-Dīn Muhammad b. Aḥmad al-Dhahabī, Tārīkh al-Islām wa-wafayāt al-mashāhīr wa-al-a'lām, ed. 'Umar 'Abd al-Salām al-Tadmurī (Beirut: Dār al-kutub al-'Arabī, 1993), vol. 48, p. 331; Zayn al-Dīn 'Abd al-Raḥmān Ibn Rajab, al-Dhayl 'alā țabaqāt al-ḥanābila, ed. 'Abd alRaḥmān b. Sulaymān al-'Uthaymīn (Riyad: Maktabat al-'Ubaykān, 2005), vol. 4, p. 380.

7 Note that the sources sometimes refer to this quarter as al-Hazzāmiyya, and that it is sometimes misspelled as al-Ḥarāmiyya or al-Ḥarāmiyyīn, cf. Ibn Rajab, Dhayl, vol. 4, p. 380; Shams al-Dīn Muḥammad b. Aḥmad al-Dhahabī, Kitāa tadhkirat al-ḥuffāz (Beirut: Dār al-kutub al'ilmiyya, 1998), vol. 4, pp. 191-192; Aḥmad Ibn Ḥajar al-'Asqalānī, al-Durar al-kāmina fì àyān al-mia al-thāmina, ed. Muḥammad 'Abd al-Mu'īd Ḍān (Hyderabad: Majlis dāirirat al-ma'ārif al-'uthmāniyya, 1972), vol. 5, pp. 8-9; al-Dhahabī, Tārīkh, vol. 48, p. 331. Yāqūt al-Ḥamawī erroneously mentions that this quarter would have contained the mausoleums of one Muhammad b. Ibrāhīm, a descendent of 'Alī b. Abī Țālib, and of 'Uzayr, the son of the Prophet Aaron. These graves are actually located in the province Maysān, see: Shihāb al-Dīn Abū 'Abd Allāh Yāqūt al-Ḥamawī, Mu jam al-buldān (Beirut: Dār al-șādir, 1995), vol. 2, p. 252; LeStrange, The Lands of the Eastern Caliphate, p. 43. Also see the introduction of Aslam b. Sahl Bahshal al-Wāsițī, Tārīkh Wāsiț, ed. Kūrkīs 'Awwād (Beirut: 'Ālam al-kutub, 1986), p. 25. 
Mas'ūd b. 'Umar al-Wāsițī al-Hazzāmī, was in fact a shaykh of the Rifā'î̀ țāifa. ${ }^{8}$ In his autobiography al-Wāsiṭi describes him as follows:

I was born and raised among a group $(t \underline{a} i f a)$ of the Aḥmadiyya [Rifā'iyya], because my father - may God forgive him! - was one of their leaders and viziers (wuzara $\left.\bar{a}^{\prime}\right)$ of their shaykhs. He was obedient [to them], maintaining a state of excessive service $\left(n a f^{\prime}\right)$ by fulfilling the needs of people, feeding [them] food, and warding off any [personal] desire, as is the way of the Ahmadiyya fuqarä. 9

We know little more of al-Wāsițîs family, except that he may have had an older brother by the name of Ishāa (as indicated by his father's kunya), and that he had a younger brother who was born approximately a year after him. The latter eventually became a Sufi shaykh in Wāsiț himself, and passed away in 738/1338, having reached a venerable age. ${ }^{10}$ The fact that al-Wāsițīs father was a Sufi shaykh and his brother too became one - perhaps also of the Rifāiiyya - shows that his family probably enjoyed a certain status in Wāsiț, and that Sufism played an important role in their lives. At any rate, the Rifāci țā'ifa certainly played a dominant role in shaping the early life of al-Wāsiți himself and, as we shall see, his experiences would soon lead him to question the proper bounds of Sufism. We will thoroughly examine this further below, where we will also discuss the Rifāiyya in more detail. However, we must first consider the background against which the first half of al-Wāsițīs life unfolded in order to better understand his trajectory.

1.1

Wàsit under the Ilkhanids

While one may expect that the Mongol conquest of Wāsit would have a deep impact on the city for years to come, I have found nothing in our sources

8 Although the quote that follows does not have al-Wāsițī referring to his father as a shaykh, he does explicitly refer to him as a shaykh in another treatise, cf. Mizān al-shuyūkh, p. 246; see also: Ibn Rajab, Dhayl, vol. 4, p. 381.

9 Al-Wāsițī, Rị̣la, p. 17. Note that the term faqīr, pl. fuqarā', which I shall transliterate throughout this book rather than translate, is a typical term by which followers of the Rifâ'iyya referred to themselves. In Sufism, it is mostly used to signify the Sufi's contentment with nothing but God, which implies a sense of poverty in this world, cf. for instance Khaliq Ahmad Nizami, "Faḳī," in $E I^{2}$ : p. 757; for the Rifā̄īs, this may very well had to do with their particular method of sober living as well, as we shall see in the next section.

10 Shams al-Dīn Muḥammad b. Aḥmad al-Dhahabī, Dhayl Tārīkh al-islām, ed. Māzin Sālim Bā Wazīr (Riyad: Dār al-mughnī li-al-nashr wa-al-tawzī‘, 1988), p. 126; al-'Asqalānī, Durar, vol. 5, pp. 8-9. 
suggesting that the ensuing period under Ilkhanid rule was particularly difficult for its inhabitants. In fact, the city was partially reconstructed and soon fared fairly well economically. The Ilkhanids annexed the city to Baghdad and had it governed by a local religious head (sadr). By the end of the century they had its mints reopened, which had previously given the city great strategic importance but had been closed since the end of the fourth/tenth century. ${ }^{11} \mathrm{~A}$ few decades into the eighth/fourteenth century the Moroccan traveler Ibn Bațtūta would describe Wāsiṭ as a city with many gardens and trees and considered its inhabitants to be among the most excellent people of Iraq. He also mentions having visited a huge madrasa that contained 300 rooms to house students who want to memorize the Qur'an. ${ }^{2}$

That Wāsit was once more prospering is not so strange in view of the fact that the Mongols actually appreciated the advantages of peace and order. The Orientalist notion that their defeat of the Iraqi caliphate commenced the destruction of Islamic civilization has since long been disproven by scholars. It has even been contended that the material damage of the conquest was exaggerated by contemporary Muslim historians in order to demonize their Mongol enemies. In practice, whenever the Mongols established themselves in a particular territory, they actually aimed to establish peace and security. ${ }^{13}$ Their interest for trade created opportunities for people of the lower class and gave rise to a whole new middle class; and their support for sciences that captured their interest led to intercultural exchange of knowledge, and gave rise to new intellectual developments in the lands they conquered. ${ }^{14}$

As for religious policy, although the first Ilkhanid rulers were non-Muslims, it appears that for the most part the predominantly Sunni population of Iraq and Iran had little trouble practicing their religion as they had before. Čingiz Khan's law secured a certain measure of religious freedom which, initially, was sustained more or less under the Ilkhanids as well. It is noteworthy in that regard that Sufi organizations, which were already gaining ground in the previous century, continued to do so under Mongol rule. ${ }^{15}$

11 Bosworth, "Wāsiț," p. 86; Sakly and Darley-Doran, "Wasit (Wāsiṭ)," p. 553, and for the mints of Wāsiț, see pp. 554-555.

Muḥammad b. 'Abd Allāh al-Ṭanjī Ibn Bațțūṭa, Riḥlat Ibn Batțūṭa al-musammāh Tuhfat al-nuzzār fì gharāìb al-amșār wa-'ajā'ib al-asfār, ed. 'Abd al-Hādī Tāzī (Rabat: Akādīmīyat al-Mamlaka al-Maghribiyya, 1997), vol. 2, pp. 7-9.

For this nuance in the scholarly view of the Mongol conquest, see for instance Bernard Lewis, "The Mongols, the Turks and the Muslim Polity," TRHS, vol. 18 (1968): pp. 49-56.

14 Ibid. See also: Beatrice Forbes Manz, "The rule of the infidels: the Mongols and the Islamic world," in NCHI: pp. 157-158.

Manz, "The rule of the infidels," pp. 154-155. 
Since al-Wāsițī left the country around the year 683/1284, we know that he lived under the rule of Hülagü (r. 654-663/1256-1265), Abaqa (r. 663-68o/12651282), Tegüder (r. 68o-683/1282-1284), and perhaps briefly under Arghūn (r. $683^{-69}$ o/1284-1291). ${ }^{16}$ When we look closer at their policy, we do find that the stance vis-à-vis religion of the first two Ilkhans, Hülagü and his son and successor Abaqa, gave rise to occasional tension between them and their Muslim subjects. While not opposed to Islam as such, Hülagü did view the Sunni caliphate as a dangerous threat to Mongol hegemony. After several Shi'ite communities had surrendered to him during his conquest, the famous Isma'ili scholar Nașìr al-Dīn al-Ṭūsī (d. 672/1274) became his personal adviser. It was in fact al-Ṭusī who encouraged him to sack the Sunni capital of Baghdad. However, after Hülagü's death not much of this apparent Mongol-Shi'ite alliance remained.

The sometimes unsympathetic attitude towards Islam under the rule of Hülagü and Abaqa also had to do with the fact that the Ilkhanate was at war with the Muslim Mamluks. Most of the Mongol elite during their reign had turned to Buddhism, while many of the women in the Ilkhanid family were Christian. They thus employed a certain religious rhetoric to justify their great military success by claiming that they enjoyed divine favor, and that their defeat of the caliphate was God's punishment of the Muslims. Moreover, without much result, they tried to capitalize religion by forging alliances with European Christian rulers to set up joint military campaigns against the Mamluks. ${ }^{17}$ In spite of this attitude, when it came to the lands under their control, they were not out to eradicate Islam. Even though there were instances where mosques were closed and estates owned by Muslims were confiscated, they never suppressed Islam or any other religion by force. Only when their Muslim subjects joined the Mamluks, in opposition to them, would they resort to violence to subdue them.

The policy soon changed in favor of Islam under Tegüder, another son of Hülagü, who had become Muslim as a young boy and taken the name Ahmad. He tried to rectify what his predecessors had done by opening new mosques and madrasas, giving back estates that had previously been confiscated, and supporting the yearly hajj pilgrimage. He also made clever use of his conversion to eliminate the legitimacy of the Mamluk rulers as the sole protectors of

16 Al-Wāsițī, Riḥla, p. 33.

17 On the ideological background of the Mongol policy in their war against the Mamluks, see the excellent study of Broadbridge, Kingship and Ideology, pp. $28-38$. 
Islam. ${ }^{18}$ And even though his successor Arghūn was a strict Buddhist, the latter could not undo all the decrees that had been instigated by Tegüder. ${ }^{19}$

\subsection{An Ilkhanid-Rifä ${ }^{\top} \grave{\iota}$ Friendship?}

All in all, it appears that the Ilkhanids were generally not hostile towards the Sunni Muslims of Mesopotamia, so that al-Wāsiți would probably have noticed little of the Mongol occupation in terms of the religious life in his native city. If anything, Wāsit may have even enjoyed the favor of the Mongol rulers. Although not explicitly mentioned in the sources, this is not unthinkable when we consider that there was likely some relationship between the Mongols and the Rifāis Sufis, who were still chiefly located in and around Wāsit in the first half of the seventh/thirteenth century. Because this provides important background to al-Wāsițī's account of the Rifāiiyya, we will briefly review the evidence for this below.

Rifâ'i sources give the impression that the early order had a deep connection with Wāsit and its direct environment. Their grand convent (riwāq) was but a day's journey from the city, in a village called Umm 'Ubayda, south of Wāsit in the marshlands of lower Iraq, the bața $i h .^{20}$ Hence, we find that besides the eponyms Ahmadiyya and Rifāiiyya - which come from the name of its founder, Ahmad al-Rifā̄i (d. 578/1182) - the ța $\bar{a}^{\prime} i f a$ was also referred to as the Bață’ihiyya.$^{21} \mathrm{Al}$-Rifấî̀'s own background in Sufism was strongly connected to the Sufi tradition of the region. He had been initiated by two local masters of Sufism: His first shaykh, the Shāfi'ìjurist 'Alī b. Muhammad Abū Faḍl al-Qurashī al-Wāsițī, known as Ibn al-Qāri' (d. 539/1144), operated in Wāsiṭ. After al-Rifā'ī had memorized the Qur'an in his father's village, he went there to study under him. This al-Wāsițī reportedly gave him ijāzas in the outward and inward sciences of Islam, and named him his sole successor (khaliffa). ${ }^{22}$ After the shaykh

18 Ibid. pp. 39-44.

19 Spuler, Die Mongolen, pp. 198-20o; Alessandro Bausani, "Religion under the Mongols," in CHIr V: pp. 538-541.

20 The Rifā'i sources always refer to grand convent of Umm 'Ubayda as al-riwāq. Ibn Bațtutța mentions that "the riwāq is a great convent (ribāt 'ażìm)." Cf. Ibn Bațtūṭa, Riḥla, vol. 2, p. 9.

21 Al-Dhahabī, Tārīkh, vol. 40, p. 255.

22 Although he is referred to in the Rifāì sources as the Shāfici shaykh of Wāsiț, I have not found any entry for him in al-Subkī's Ṭabaqāt al-shäficiyya. For traditional Rifā̄ī views of him, see Aḥmad b. Muhammad al-Witrī, Rawḍat al-nāzirīn wa-khulāsat manāqib alșāliḥin (Baghdad: [publisher unknown], 1976), p. 17; Hāshim b. Sađd al-Aḥmadī, Ghanimat al-farīqayn min hikam al-ghawth al-Rifã đ̇A Abì al-'Alamayn, ed. Aḥmad Ramzah b. Hammūd Juḥā Abū al-Hudā (Published by the author, 2014), p. 144; 'Izz al-Dīn Aḥmad al-Fārūthī, Irshād al-muslimīn li-ṭarīat shaykh al-muttaqinn, ed. Aḥmad Ramzah b. Ḥammūd Juhāā Abū al-Hudā ([Egypt?]: Dār al-țibā'a al-āmira, 2011), pp. 38-41, p. 78; 'Izz al-Dīn Aḥmad b. 
passed away, al-Rifā'ì turned to his second spiritual master, his paternal uncle, shaykh Manșūr b. Yaḥyā al-Bațāiḥ̄i (d. 540/1145), who was born in Umm 'Ubayda and had established a grand convent by the Tigris River near Wāsiț. In the year of the latter's death, he also appointed his nephew al-Rifāī as his successor and left all his convents to him, thereby putting him in charge of his legacy. ${ }^{23}$ This shows that even before al-Rifā'ī made a name for himself as a Sufi authority, the roots of his movement were already anchored in Wāsiṭ and the adjacent marshlands.

His influence in the region would only expand further in the years that followed his appointment as the successor to both his shaykhs, so that it may have even become somewhat of a Rifā̄ì bastion. After al-Rifācī chose his native town Umm 'Ubayda as his headquarters, this became the spiritual center of his order, with Wāsit as its nearest intellectual center. We thus find that preachers (wu“āa) from Wāsit would come to al-Rifā'î’s lectures (majālis) about Sufism in Umm 'Ubayda and ask him questions about all kinds of subjects. ${ }^{24}$ We also find that a number of his most distinguished followers were Shāfīi jurists from Wāsit. ${ }^{25}$ On that basis it becomes plausible to assume that when the father of our al-Wāsiți is referred to as "the shaykh of Hazzāmūn's inhabitants," as mentioned above, this indicates that at least this particular quarter of Wāsit was dominated by the Rifā'iyya. It is difficult to determine the extent to which other orders of that time, such as the Qãdiriyya and the somewhat later Suhrawardiyya, were also successful in gaining a following in this area. As a local order, the Rifāiiyya clearly had a great advantage over their fellow Iraqi competitors, many of whom were perhaps still much more rooted in Baghdad. ${ }^{26}$

It is not exactly clear when, how, and to what degree the Ilkhanids formed a relationship with the Rifāiyya. The report that speaks of the earliest contact between them is, to my knowledge, al-Dhahabì's story of how the

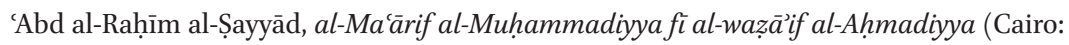
1305/1888), pp. 31-33.

23 Al-Aḥmadī, Ghanimat al-farìqayn, p. 142; al-Fārūthī, Irshād al-muslimīn, pp. 49-52.

24 'Abd al-Karīm b. Muhammad al-Rāifīi, Sawād al-'aynayn fì manāqib al-ghawth Abì alAlamayn (Al-Muhammadiyya (Egypt): al-Mațbaca al-Mīriyya, 1884), p. 7.

25 Al-Fārūthī, a contemporary of al-Wāsițī who will be discussed further below, is himself a good example of one such shaykh. He was definitely an important figure in the Rifā'iyya of Wāsiț, especially because he was also a celebrated jurist there. He himself gives an overview of what he calls the elite of al-Rifấi's direct followers; out of the 19 entries he gives, five are scholars from Wāsit, two come from nearby villages, and the rest from other cities in Iraq. See al-Fārūthī, Irshād al-muslimīn, pp. 224-253.

26 According to Trimingham, the early Qādiriyya remained very much a Baghdadi order, cf. J. Spencer Trimingham, The Sufi Orders in Islam (New York: Oxford University Press, 1998), pp. 37-40; for the Suhrawardiyya, see: Bausani, "Religion under the Mongols," p. 545. 
above-mentioned third Ilkhan, Tegüder, converted to Islam. This would have occurred after he witnessed Rifāi $\overline{1}$ fuqarā’ perform a spectacle by walking on fire before his father, Hülagü. According to al-Dhahabī, that was also the reason why Tegüder chose Ahmad as his Muslim name, after the țăiff's eponymous founder. ${ }^{27}$ If indeed historically grounded, this would show that the first Ilkhan, Hülagü, had already noticed the Rifā̄īs, and that Tegüder may very well have favored them when he came to power. Although Reuven Amitai rightfully states that al-Dhahabì's report is not on the whole unproblematic, we should not immediately discard it when we consider other insightful references to the link between the Ilkhanids and the Rifāis. ${ }^{28}$ Another example is again found in al-Dhahabīs Tārīkh, where he mentions a "misguided individual" by the name of Khalīl Ibn Badr (d. 642/1244), who claimed to be a Rifấī Sufi. Al-Dhahabī rebukes him for dressing like the Qalandariyya, drinking wine, eating hashish, and, most importantly, for gaining a position of power for himself through the Mongols (taqawwa $\bar{a}$ bi-al-tatār). ${ }^{29}$ Something similar is found concerning one Șâliḥ al-Aḥmadī al-Rifā'ī (d. 707/1307), a Rifāīi shaykh who, according to Ibn Kathīr, was honored by the Mongols when they reached Damascus at the beginning of the eighth/fourteenth century, trying once more to expand into Mamluk territory. If we are to believe Ibn Kathī's account, the Mongol general Qutlughshāh even stayed with him in his house during this episode. ${ }^{30}$

While by no means conclusive, such reports do provide some background for al-Wāsițī's bitter words about the Rifā'iyya in his autobiography, where he reflects on his days as a youth with them. After severely criticizing several of the practices he claims to have seen among them, he concludes:

That is why it is only right that the Mongols (al-tatar) have come to rule their land and gained mastery over them! In fact, they are content [having them] in their country, because [the Mongols] believe in them and venerate them. ... Perhaps the last caliphs of Baghdad only came to an end for the simple fact that they did not disavow these kind of things [that the Rifā̄is do]; for instead of changing this [behavior], they preserved it for them - and that is why God brought them to an end! ${ }^{31}$

27 Al-Dhahabī, Tārīkh, vol. 51, p. 140.

28 Reuven Amitai, "The Conversion of Tegüder Ilkhan to Islam," JSAI 25 (2001): pp. 18-20.

29 Al-Dhahabī, Tārīkh, vol. 47, p. 118.

$30 \quad$ Abū al-Fidā’ Ismācīl b. 'Umar Ibn Kathīr, al-Bidāya wa-al-nihāya, ed. 'Alī Shīrī (Beirut: Ḍar ihyā’’ al-turāth al-'arabī, 1988), vol. 14, p. 52.

31 Al-Wāsițī, Rị̣la, p. 19. 
A few pages later, he makes a similar statement, saying: "What I believe is that, God willing, the only way for the Mongols to overpower the people of Islam is through the evil of these groups," by which he explicitly refers to those who follow Ahmad al-Rifā'î and other shaykhs like him. ${ }^{32}$ If we take the above into account, we can with some caution conclude that there must have indeed existed a friendly relationship of some sort between the Rifā'iyya and the Mongol rulers.

It is in the atmosphere described above that al-Wāsițī would grow increasingly uncomfortable with the traditions and customs that his father - and probably his family also - adhered to. The next section will be devoted specifically to this chapter of his life, by offering a historical analysis of his views on the Rifā'iyya. This will be followed by a section on al-Wāsițìs final years in Iraq.

\section{$2 \quad$ Al-Wāsițī versus the Rifā'iyya}

Although the passages about the Rifāciyya from al-Wāsițīs autobiography appear to have a purely polemical function, they can tell us something about their practices in the area of Wāsit around the middle of the seventh/thirteenth century; and although al-Wāsiṭi does not disclose a lot about his personal life during his time in Wāsiț, reading between the lines sometimes reveals the struggle of a young critical mind seeking the path he sees most fitting to arrive unto God spiritually - wușūl, as he often calls it. We thus find that while he likes his readers to believe that his disdain for the ways of the Rifā̄i Sufis resulted from divine guidance, there was clearly an element of individual research at play. He tells us:

One of the graces that God (T) bestowed upon me is that He created an instinct in me during my childhood (al-hâal al-țuüliyya) by which I used to know that they have no basis [for their practices], and that the truth is beyond that which they call to. I would hold fast to al-Qushayrī's Risāla, the Kitāb al-Qūt, and the Ihy $\bar{a}$. I was inherently aware of their falsehood, although it is practically impossible to bring it to light because they are in power [in the region] (al-dawla lahum). Thus, there is no possibility at all to expose it! 33

$32 \quad$ Ibid. p. 25 .

33 Ibid. pp. $26-27$. 
This statement implies that, as I suggested before, the Rifāiyya was indeed dominant in the region, to the extent that it was difficult to express criticism towards the order's practices. It also shows that al-Wāsițì's critical attitude would have derived, at least partially, from an individual study of classical Sufi manuals. Abū al-Qāsim al-Qushayrì’s Risāla, Abū Ṭālib al-Makkī's Qūt al-qulūb, and Abū Ḥāmid al-Ghazālì's Ihyy a' 'ulūm al-dìn to which he refers here were not only technical manuals on the Sufi way, but were all to a certain extent meant to defend its legitimacy as an Islamic science as well. The form of Sufism propounded therein may therefore have appeared much more sober and scholastic to our still young Iraqi Sufi than what he observed from the Rifāi 1 fuqara $\vec{a}^{3}$ around him. ${ }^{34}$

But what exactly did he observe, and in how far can we verify the veracity of his statements? Since scholars to date have written but very little on the early Rifāciyya, this endeavor requires a critical comparison between al-Wāsițîs descriptions as found in his autobiography and what Rifāī sources tell us about their doctrines and rituals. By comparing the accounts from both sides we can in some measure historicize them.

For that purpose, we will refer to five of the earliest available books concerned in some way with the Rifāi țăi ifa by affiliated scholars, some of whom were contemporaries of al-Wāsiți. 35 These are:

- Ghanimat al-farīqayn min hikam al-ghawth al-Rifä̀ Abì al-Alamayn by one Hāshim b. Sad al-Ahmmadī (533-630/1139-1233), an otherwise unknown figure who was initiated by al-Rifā̄i himself. ${ }^{36}$ This work, which opens with a biography of al-Rifā̄i $\overline{1}$, consists of discourses and epistles related from the shaykh.

- Sawād al-'aynayn fì manāqib al-ghawth Abì al-Alamayn by the celebrated Shāfíi jurist 'Abd al-Karīm b. Muḥammad al-Rāfi'ì al-Qazwīnī (555623/116o-1226). ${ }^{37}$ As indicated by its title, this is a biography of al-Rifā̄i $\overline{1}$. It is

34 For the scholastic nature of these works, see for instance: Éric Geoffroy, Le soufisme en Égypte et en Syrie sous les derniers Mamelouks et les premiers Ottomans: orientations spirituelles et enjeux culturels (Damascus: Institut français d'études arabes de Damas, 1995), p. 95 .

35 I have used Aḥmad Ramzah b. Ḥammūd Juhā Abū al-Hudā’s extensive overview of the earliest Rifā̄ì sources for the list presented here, as found in his introduction to al-Fārūthī, Irshäd al-muslimin, pp. 24-25.

36 Ibid. p. 24 .

37 The colophon of this book mentions Rajab 588/July 1192 as its date of completion, cf. alRāfī̄, Sawād al-'aynayn, p. 29. Although omitted in the list of al-Rāfi'i’s works found in al-Subkī's Tabaqāt, there is no reason to doubt its authenticity, especially in light of the fact that al-Fārūthī cites from it twice in his Irshād, cf. pp. 108 and 209; for the list, see Tāj al-Dīn 'Abd al-Wahhāb al-Subkī, Țabaqāt al-shāfíiyya al-kubrā, ed. Maḥmūd Muḥammad 
noteworthy that, although not widely attested to, the author was reportedly initiated into the Rifấiyya by al-Ṣayyād, who composed the next work on our list. ${ }^{38}$

- Al-Ma'ārif al-Muhammadiyya fì al-wazāî̉ al-Ahmmadiyya by 'Izz al-Dīn Ahmmad b. 'Abd al-Rahīm al-Ṣayyād (574-670/1178-1271), a grandson of alRifā̄ī who eventually founded a separate Rifāī branch. ${ }^{39}$ This work is unique in our list in that it is the only explicit Rifāì Sufi manual, thus providing the most detailed account of the ță iffa's doctrines and rituals.

- The final two works on our list are particularly important in that they were both written by 'Izz al-Dīn Ahmad b. Ibrāhīm al-Fārūthī (614-694/12181295), who was one of al-Wāsițīs teachers in Shāfíi jurisprudence. ${ }^{40}$ In that light, his writings not only represent the views of an important contemporary in time, but also in space, as he was probably the most distinguished hadìth-scholar and jurist of Wāsiṭ during the years al-Wāsițī lived in his native city. ${ }^{41}$ And since al-Fārūthī is known to have invested people with the Rifā̄ī Sufi cloak (khirqa), it is likely that he was also one of Wāsiț's chief Rifāīi shaykhs. ${ }^{42}$ His first work on the order, al-Naf̣ha al-miskiyya fi al-suläla

al-Ṭanāḥī \& 'Abd al-Fattāḥ Muḥammad al-Ḥulw (al-Muhandisīn, Jīzah: Hajar li-al-țibāáa wa-al-nashr wa-al-tawzī', 1992), vol. 8, pp. 281-282.

38 Al-Rāfi'ì's initiation by al-Ṣayyād is attested to by al-Fārūthī. Note that al-Fārūthī may very well have been a disciple of al-Rāfi'i when he was still an adolescent, as he calls him "our shaykh," something which could further support al-Rāfi'ì's Rifācī affiliation; see al-Fārūthī, Irshād al-muslimīn, pp. 108 and 205. Al-Subkī does not mention any connection to Sufis in his entry of al-Rāfi'ì, although he does relate that he was a renunciant (zāhid) who performed miracles (karāmāt); al-Nawawī reportedly called him "one of the righteous who reached the state of stability (al-șāliḥin al-mutamakkinin)," stability (tamkin) being the final stage of the spiritual path in Sufi terminology, cf. al-Subkī, Țabaqāt al-shäficiyya, vol. 8, pp. 283-284.

39 According to al-Fārūthī, al-Ṣayyād left Iraq in 622/1225 out of pious fear for his growing fame there, which could threaten his spiritual state. He traveled through the Hijāz, Yemen, Syria, and finally settled in Egypt, initiating pupils and opening convents (ribäts) along the way. Cf. Irshād al-muslimìn, pp. pp. 203-210; see also: C. Edmund Bosworth, "Rifā'iyya," in $E I^{2}$ : vol. 8, p. $5^{25}$.

$40 \quad$ Ibn Rajab, al-Dhayl, vol. 4, p. 381.

41 He is referred to in several biographical dictionaries as the shaykh of Iraq, see for instance: 'Afîf al-Dīn 'Abd Allāh b. As'ad al-Yāfi'ī, Mir'āt al-jinān wa-'ibrat al-yaqzān fì ma'rifat mā ya'tabaru min ḥawādith al-zamān, ed. Khalīl al-Manșūr (Beirut: Dār al-kutub al-ilmiyya, 1997), vol. 4, p. 167; and: Taqī al-Dīn Abū al-Faḍl Muhammad Ibn Fahd, Laḥz al-alhāz bidhayl țabaqāt al-ḥuffāz (Beirut: Dār al-kutub al-'ilmiyya, 1998), p. 6o. 
al-Rifäiyya al-zakiyya, is a short epistle devoted to the genealogy of al-Rifāìi. His second work, Irshād al-muslimin li-taríqat shaykh al-muttaqin, is a much larger volume that contains biographies of al-Rifā̄ì and his most distinguished followers up to al-Fārūthī's time, and cites several of al-Rifā'ī's discourses and litanies (sing. hizb, pl. aḥzāb).

In order to systematically compare the views expressed by al-Wāsiṭī and his Rifāî̀ counterparts, we will analyze three general themes: The first concerns the position and role of the shaykh, or spiritual master, in the order; the second concerns the practice of the Rifā̄iss, which focuses on their gatherings of Sufi audition $(s a m \bar{a})$ and miracle-working; the third theme brings the former two together to see what the overall depictions of the Rifāiyya can tell us about them. This is followed by a concluding discussion to scrutinize how our understanding of the tă $i f a$ can be of value to the scholarly discourse on the form of Sufism practiced in al-Wāsițīs early Iraqi context.

\subsection{Shaykhdom in the Rifä iyya}

One of the first matters that al-Wāsiți addresses with regard to the Rifāīs in his autobiography pertains to the position that they assign to their shaykhs. According to his observation, they consider the shaykh to be someone with extraordinary capabilities, who, for reasons he does not explicitly disclose, plays a pivotal role in their lives:

failing to acknowledge his Rifāī affiliation, cf. Taqī al-Dīn 'Abd al-Raḥmān al-Wāsițī, Tiryāq al-muhibbīn fi țabaqāt khirqat al-mashāyikh al-'ārifīn (Cairo: Mațba'at Muhammad Mușțaāa, 1305/1888), p.18, as cited by Ohlander, "Fārūthī”; see also: al-Yāficī, Mir'āt, vol. 4, p. 167; al-Subkī, Țabaqāt, vol. 8, p. 6; Ibn Kathīr, al-Bidāya , vol. 13, p. 404. However, alFārūthì's own two works mentioned above conclusively show that he first and foremost considered himself a Rifāī Sufi. Al-Nafha al-miskiyya was written in in 675/1276 (as mentioned by al-Fārūthī in the book itself on p. 4); in it, we find al-Fārūthī praising God for the blessing of having made him one of al-Rifāī's followers, see: al-Fārūthī, al-Nafṭa al-miskiyya fì al-sulāla al-rifāìyya al-zakiyya (al-Āsitāna al-'Aliyya: Maṭba'at Muḥammad As'ad, 1883), p. 11. His Irshäd al-muslimīn was written in 684/1285 (as mentioned by alFārūthī in the book itself on p. 267); here we find al-Fārūthi saying it is not allowed for a Rifā̄i faqìr to join any other țẳifa, because the Rifāiiyya contains all the distinguished secrets of servitude and the spiritual realities of Muhammadan wisdom, cf. p. 115. Both works repeatedly state that Aḥmad al-Rifāīi was the greatest shaykh of all times, thereby asserting the superiority of his țẳifa. Both works also show that al-Fārūthī grew up in a family of loyal Rifā̄i Sufis. He relates two silsilas that connect him to al-Rifā̄î̀, as can be seen in appendix 1, p. 68, and also: al-Fārūthī, al-Naf̣̂a al-miskiyya, pp. 13-14. This shows that al-Fārūthī would not only have invested pupils with the khirqa of the Suhrawardiyya, but very likely also that of the Rifāiyya. For Ohlander's doubt concerning which khirqa exactly he invested, cf. Sufism in an Age of Transition, pp.114-115, n165. 
Instead of worship, it is their shaykhs who are firmly settled in their hearts, so that they turn to them during calamities and invoke them during their mishaps. The shaykh is to his followers like a prophet - in fact, it may be that they venerate him more than they venerate the prophets! For instance, they lower their heads in prostration and uncover them when they are in his presence, seeking refuge from his anger and his spiritual and hidden punishments ('uqūbātihi al-bāținiyya al-ghaybiyya). They believe that he utters whatever he desires, that he can make the living die, heal the sick, and shoot his arrow at anyone he likes, thereby killing that person! ${ }^{43}$

Our Iraqi Sufi hardly mentions the founder of the order, Aḥmad al-Rifā'īi but is

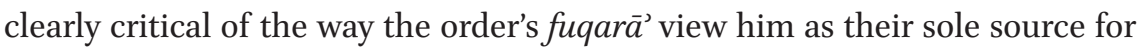
religious life: "They have no desire for the conduct ( $\bar{a} d \bar{a} b)$ of the Messenger $(S \subseteq)$ in their worship and practices. Instead, they desire the lifestyle of their grandshaykh (sirat shaykhihim al-akbar)" 44 - which is without a doubt in reference to al-Rifāì

It is highly likely that there was indeed a strong emphasis on the shaykh in the early Rifāi 1 țài $i f a$ already. Al-Ṣayyād's manual is quite explicit regarding the proper conduct that the faqir should have with the shaykh whom he has taken as his spiritual guide (murshid), and proudly states that "the Ahmadiyya have the strongest reverence ( $\left.\operatorname{ta} \mathrm{z}^{\mathrm{i}} \mathrm{im}\right)$ for their shaykhs." ${ }^{45}$ This reverence manifested in specific etiquettes that were to be upheld in the presence of the shaykh, such as the example of uncovering one's head in his presence given by al-Wāsiți above, something which Ibn Taymiyya confirms as a habit practiced by Rifācī Sufis. ${ }^{46}$ Such reverence is explained by al-Ṣayyād in a section of his manual wherein he names the fundaments of Rifāi $\bar{s}$ sulük, the method used to achieve spiritual realization. These are specified as follows: The faqï begins by sending prayers (șalāt) upon the Prophet Muhammad and perfecting the obligatory and supererogatory acts of worship, after which he should turn himself to the direction of prayer (qibla) and connect his heart to the spiritual guide (murshid). The first station in Rifā'i sulük is then to be annihilated in the shaykh (maqām al-fanä' fí al-shaykh), so that the faqïr subjects himself to him completely and is fit for his tarbiyya, his spiritual training in the Sufi way. It is only

43 Al-Wāsițī, Rihlala, p. 17.

44 Ibid. p. 18.

45 Al-Ṣayyād, al-Måāifi al-Muhammadiyya, p. 117.

46 Ibn Taymiyya, Majmū Fatāwā (henceforth $M F$ ), ed. 'Abd al-Raḥmān b. Muḥammad b. Qāsim (Riyad: Wizārat al-shu'ūn al-islāmiyya wa-al-awqāf wa-al-da'wat wa-al-irshād, 1995), vol. 11, p. 494. 
then that he can continue to become annihilated in the Prophet (fana $\bar{a}^{\prime} f \imath$ alrasūl), after which he will finally become susceptible to annihilation in God

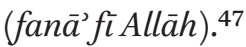

As for the special feats attributed to the Rifāīi shaykhs, al-Wāsițīs description of their special powers seems very much in line with the manner in which Aḥmad al-Rifăì's's status as a friend of God (sing. walī, pl. awliy $\left.\bar{a}^{\prime}\right)$ is portrayed by his followers. Al-Ahmadī, for instance, relates a discourse from al-Rifā̄ī himself about the rank known as the ghawth, the helper. He defines it as the station in which the friend of God has the power to freely dispose, forbid, and command atoms (maqām al-tașarruf wa-al-nahȳ wa-al-amrfì al-dharrāt), which is highly reminiscent of what certain Sufis associate with the technical term 'himma,' the creative power God grants His closest friends. ${ }^{48}$ The same discourse goes on to explain that every age knows a shaykh who is raised to this station and thereby becomes a representative of Muhammad on earth (näaib an an al$n a b \bar{\imath}) .{ }^{49}$ That al-Rifāì ì was actually referring to himself by this description is by no means left to speculation. He is quoted, saying: "Truly - and God be praised! - I possess this rank (martaba) and inherited the chain of this Muhammadan representation (al-niyāba al-Muhammadiyya). ${ }^{50}$ In a hagiographic tale, alFārūthī relates that, before al-Rifāììs birth, some of the greatest friends of God anticipated his coming and ordered their companions to follow him if they were to live long enough. They acknowledged that he would be the master of his age, which would be under his command and disposal, and that the power (dawla) would belong to him and his household (dhurriyya) until the Day of Judgment. ${ }^{51}$

His supreme position in the hierarchy of God's friends alluded to here is something all our Rifāīi authors explicitly agree on. It would surely have been

$47 \quad$ Ibid. pp. 122-123.

48 It is interesting to note that Najm al-Dīn Kubrā (d. 618/1221), the eponymous founder of the Kubrawiyya order, is responsible for a distinct interpretation of the term himma, which subsequently spread in Persia and Central Asia. In his doctrine, it is associated with a high spiritual rank of friendship with God wherein the friend of God has free disposal (tașarruf) and can thereby perform supernatural feats as he pleases. While it may appear problematic that the friend of God is gifted with a kind of spiritual control in the physical world, which seemingly blurs the line between God and servant, it is argued that the ultimate source of this power is God. For a good overview of the theory behind this term in the works of several Sufis, see: Lloyd Ridgeon, 'Aziz Nasafi (Richmond: Curzon, 1998), pp. 159-165, and also Annemarie Schimmel, Mystical dimensions of Islam (Chapel Hill: University of North Carolina press, 1975), p. 257.

49 Al-Aḥmadī, Ghanìmat al-farīqayn, pp. 8o-82.

50 Ibid. p. 82.

$5^{1} \quad$ Al-Fārūthī, al-Naf̣̣a al-miskiyya, p. 10. 
this conviction that led to the critical importance of his persona to the lives of his followers, which induced al-Wāsițī to censure them as we have seen. They would call al-Rifầì by the honorific 'Abū al-Alamayn,' literally 'the father of the two distinguishing marks,' which al-Rāfi'ì and al-Ṣayyād explain as referring to his attainment of both the station of the ghawth and the qutb, the latter signifying the spiritual axis and the leader of the friends of God. ${ }^{52}$ This certainly puts in perspective al-Ṣayyād's statement that it is obligatory for every Rifāì faqir to know the rank of their founding shaykh, because for them the spiritual path and the shaykh were intertwined, and hence two sides of the same coin. ${ }^{53}$

Another aspect of al-Rifā'ì's high spiritual rank that we find repeated in all the works of our Rifā'i shaykhs is his genealogical link to the family-line of the Prophet Muhammad. Al-Fārūthī's Naf̣̣a has no other purpose but to demonstrate that al-Rifā'ī was part of the Prophetic genealogy. ${ }^{54}$ In his Irshād he tells us that the cloak of initiation of the Banū Rifā'a is thence called 'khirqat Ahl al-Bayt,' the cloak of the Prophetic Household, because al-Rifā'î's Sufi genealogy (silsila) consists entirely of descendants of the Prophet. ${ }^{55}$ Likewise, alAhmadì and al-Rāfi'i both give us the complete silsila of their shaykh, with the latter adding that there was once a man who had disavowed its authenticity, only to affirm it after Fāțima, the Prophet's daughter, rebuked him for that in a dream. ${ }^{56}$ It is because of this claim to genealogy that al-Ṣayyād devotes several pages in his Sufi manual to love for the Ahl al-Bayt, which he considers a re-

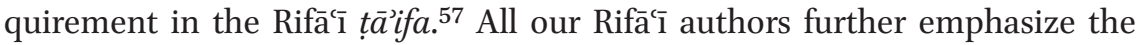
profound relationship between al-Rifā̄ī and the Prophet by relating a miracle (karāma) that would have occurred during the shaykh's visit to Medina when performing his hajj. It is said that when he greeted the Prophet with the words "peace be upon you my grandfather," the Prophet replied to his greeting, saying "and peace be upon you my son." When the Prophet then stretched out his hand from the grave, al-Rifā'i kissed it. ${ }^{58}$ In combination with his genealogical connection, his followers' belief that such this-worldly and physical contact with the Prophet actually occurred would not only have affirmed his high spiritual rank to them, but also his exceptionally close affinity to the Prophet.

\footnotetext{
52 Al-Rāficī, Sawād al-'aynayn, pp. 15-17; al-Șayyād, al-Ma'ārif al-Muḥammadiyya, pp. 6o-62.

53 Al-Ṣayyād, al-Máāifif al-Muhammadiyya, p. 31.

54 Al-Fārūthī, al-Nafḥa al-miskiyya, pp. 4-7 and p. 13.

55 Al-Fārūthī, Irshād al-muslimìn, p. 37 and p. 73.

56 Al-Aḥmadī, Ghanìmat al-farīqayn, pp. 19-24; al-Rāfīì, Sawād al-‘aynayn, p. 4.

57 Al-Șayyād, al-Ma'ārif al-Muhammadiyya, pp. 26-31.

$5^{8}$ Al-Ṣayyād, al-Ma'ārif al-Muhammadiyya, p. 59; al-Rāfíī, Sawād al-'aynayn, pp. 10-11; alAḥmadī, Ghanìmat al-farīqayn, p. 25; al-Fārūthī, Irshād al-muslimìn, pp. 88-9o and p. 165.
} 
Undoubtedly related to this affinity is what may be seen as Shi'ite inclinations in the early Rifā'ì order. Both al-Fārūthī and al-Aḥmadī state that al-Rifā'ī was the greatest friend of God after the Prophet's Companions (șahāba) and the twelve Imams of the Prophetic family-line (a'immat al-älal-ithnay 'ashar). ${ }^{59}$ We also find al-Fārūthī stating that one shaykh once had a dream in which the Prophet said to him: "My son Ahmad [al-Rifā̄ī] is the thirteenth Imam of guidance from my Household (Ahl Baytī)." Obviously aware of the Shi'ite connotation, al-Fārūthī adds that every knower of God ('ārif) affirms the twelve Imams, who were themselves knowers, although not in the sense of those who assert that they were infallible. ${ }^{60}$ This remark is, of course, directed at the way the Shi'ites view the Imams. High regard for the twelve Imams in our sources is not necessarily surprising, as the possible influence of Shi'ism on Sufism in this particular context has been noted before. In his chapter on religion under the Mongols in Iran, Allesandro Bausani speaks of "Sufism with a Shi'i tinge" as the most important religious feature of this context. ${ }^{61}$ While the Rifāi ì sources cited above seem to support Bausani's observation, we must at the same time be careful not to underestimate the importance of the Ahl al-Bayt in Sunni tradition, especially in the Sufi orders, where we frequently find that silsilas are traced back to the Prophet's cousin and son-in-law, 'Alī b. Abī Taalib.

In any case, al-Wāsiți too speaks of Shi'i tendencies in his critical account of the Rifāiyya. He brings this up in relation to the ța $i f a$ 's practices surrounding the visitation (ziyāra) of the Rifāì mausoleum in Umm 'Ubayda:

When I was a child, they would take me to visit the mausoleum (ziyanrat qubba) of the shaykh [Ahmad al-Rifāì], traveling by mount to the village in which he is buried (that being Umm 'Ubayda). Whenever the

59 Al-Aḥmadī, Ghanimat al-farīqayn, p. 25; al-Fārūthī, Irshād al-muslimīn, pp. 106-107.

6o Al-Fārūthī, Irshād al-muslimīn, p. 106.

61 Bausani, "Religion under the Mongols," p. 547. Éric Geoffroy likewise states that Sufism in the Turco-Persian world of our context contained crypto-Shi'ite influences, cf. Le soufisme, p. 66. Another example of the influence of Shi'ism on Sufism can be found in the works of the seventh-/thirteenth-century Transoxanian Sufi 'Azìz Nasafì. Although coming from a Sunni background, there are clear influences of Isma'îlism in his Persian writings. The concept of the twelve Imams is hinted at in what he quotes from his own shaykh, Sacd-alDīn-e Hammūya (d. 65o/1252) of the Kubrawiyya order, who stated that there can only be twelve friends of God (awliya $\vec{a}^{\prime}$ ) in the Muslim community; see: Hermann Landolt, "Nasafi, 'Aziz." EIr. Lloyd Ridgeon remarks that while some scholars have thus considered Nasafi a sort of Shi'ite Sufi, none of the Shi'ite tendencies in his writings are convincing enough to put forth such a claim (Ridgeon, 'Aziz Nasafi, pp. 190-195). The same, of course, goes for the Rifāiiyya: while we may discern matters that could have been influenced by Shi'ite theology, I have not come across anything in my study of our sources that would in any way imply a strong Shi'ite element in the țăiifa. 
mausoleum came in sight, they would uncover their heads and implore [God] and supplicate [Him], and sometimes they would also cry and weep. Their hearts would become tender and they would pray for their needs. Then, when coming to the gate of the shaykh's mausoleum, they would uncover their heads and prostrate on its threshold, and I, in my youthful innocence, would prostrate with them. They would stand still at its gate in a state of humility for a long time - and God knows that they do not attach such great importance to the Ka'ba as they do to the mausoleum of the shaykh! But whenever they would see the mausoleum of the shaykh, who would have the courage to enter it? In fact, among them are some who had reached a venerable age, who have no notion of what is inside the mausoleum! There is also a column in the convent (riwāq), and they would circle around this column seven times. ${ }^{62}$ Thus, standing still (wuqūf) at the gate of the mausoleum is like 'Arafa and this column is like the Ka'ba, so that it becomes like a pilgrimage ( ajjj $\left.^{a n}\right)$ to them, in the same way as the Rāfida [i.e. the Shi'ites] perform pilgrimage to the grave of Ḥusayn! ${ }^{63}$

Al-Wāsitị goes on to write that it was related to him about one of their shaykhs: "that he would enter a state of ritual consecration (ihrām) whenever the mausoleum came in sight and that he would divest himself of his tailored garments so that he could enter the village [Umm 'Ubayda]. He would reach the aim of his ziyāra and then release himself from his state of ihrām." ${ }^{\prime 4}$

Of particular interest here is how he compares the practices of the Rifäis during ziyāra with the hajj pilgrimage. Although none of the Rifāì sources describe these particular acts of entering the state of ihrām, wuqū f, and țawäf, it is known that in some places of the Muslim world the practice of ziyāra did indeed closely follow the hajj rituals, and may have occasionally functioned as a substitute for the hajj. ${ }^{65}$ While this is not necessarily something that is peculiar to Shi'ites, it is also true that the ziyāra of shrines constituted an integral part of Shi'ite practice, especially when it came to the grave of Husayn, the grandson of the Prophet. ${ }^{66}$ However, our Rifāī sources make no mention of a particular set of rituals that ought to be practiced upon visiting the mausoleum, so it is

\footnotetext{
62 The act of circumambulating the Ka'ba, țawäf, is one of the rituals during the Muslim pilgrimage (hajj).

63 Al-Wāsițī, Riḥla, p. 20.

64 Ibid. p. 21. Note that the state of ihrām is a legal requisite to perform hajj.

65 See for instance Josef W. Meri, The Cult of Saints Among Muslims and Jews in Medieval Syria (Oxford: Oxford University Press, 2002), pp. 135-138.

66

Ibid. pp. 140-141.
} 


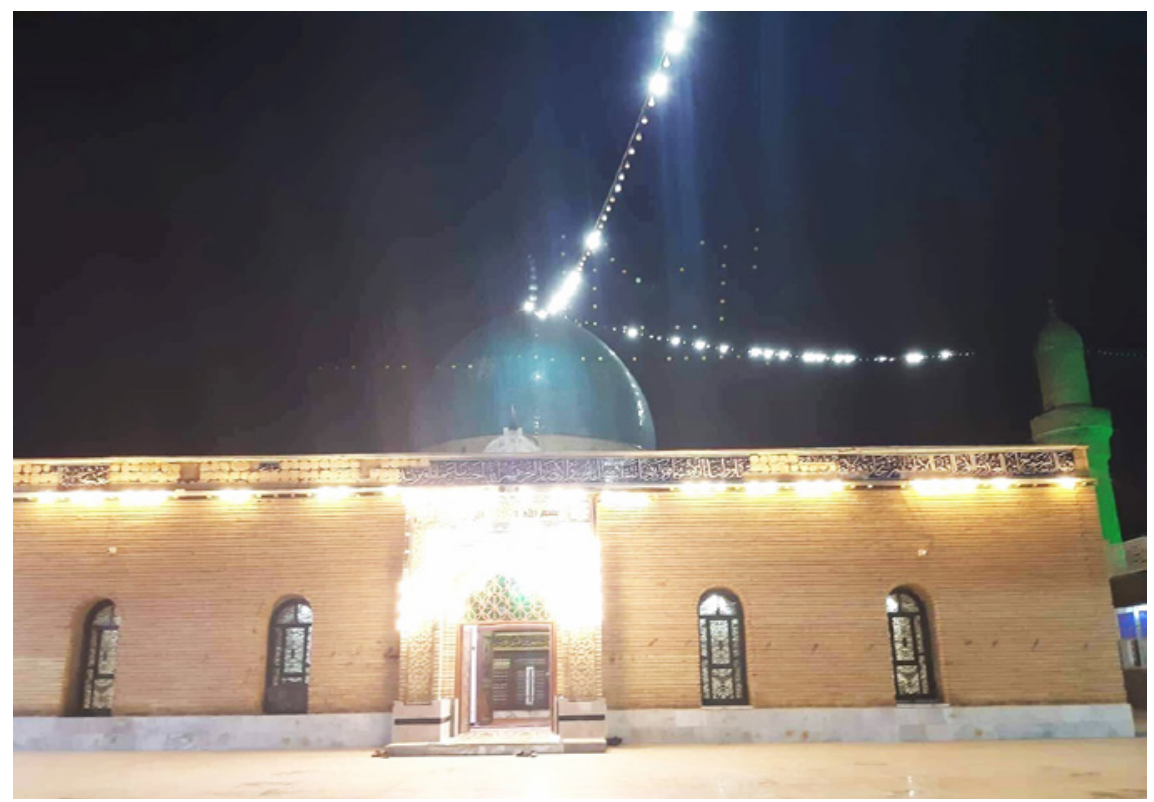

FIGURE 4 The current-day mosque that contains the Rifāề mausoleum in Umm 'Ubayda. (C) AHMAD MAHDI SALIH

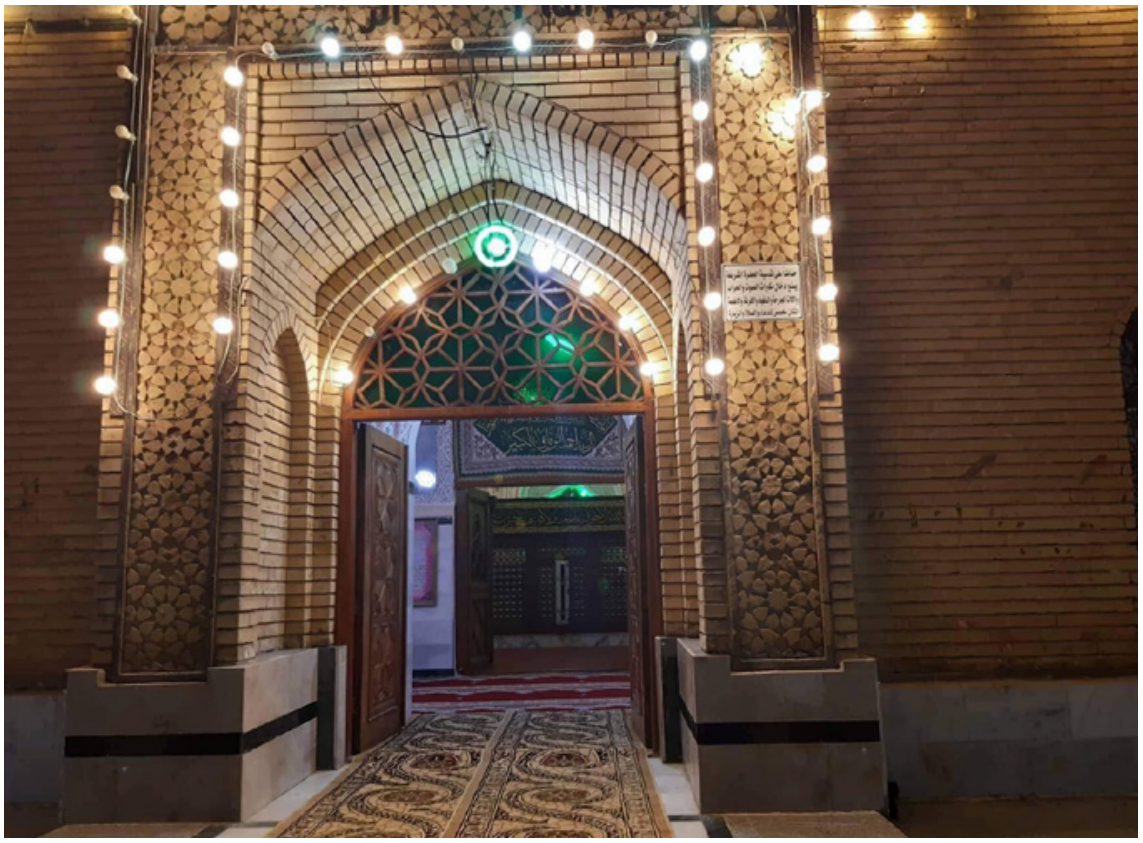

FIGURE 5 The entrance to the mosque of Aḥmad al-Rifāì̄.

(C) AHMAD MAHDI SALIH 


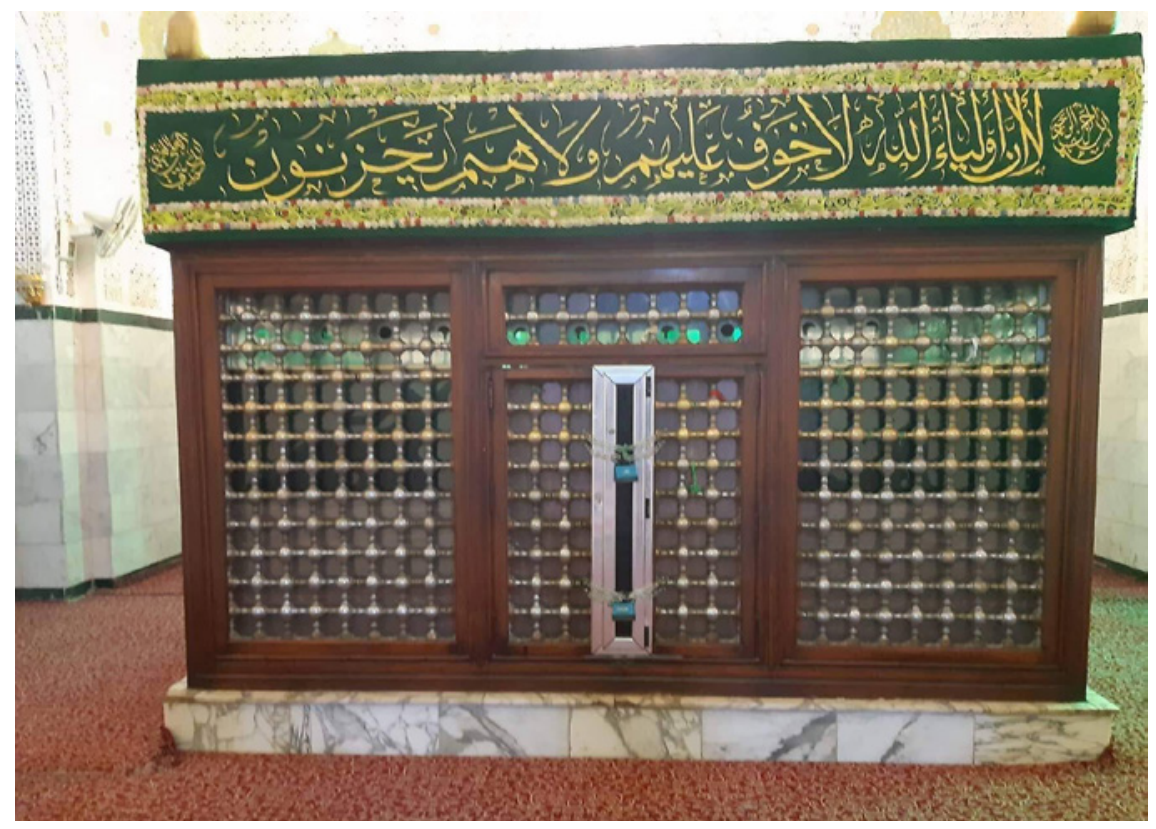

FIGURE 6 The mausoleum of Aḥmad al-Rifāīì.

(c) AHMAD MAHDI SALIH

impossible to judge how far al-Wāsitīs observations were standardized customs in the order.

What his observations do tell us, and what is corroborated by our other sources, is that the shaykh continued to play an important role in the lives of his followers after his death as an object of ziyāra. They would hold festivals (sing. mawsim, pl. mawāsim) in honor of al-Rifāìi, which would start on Thursday evenings, and went hand in hand with public sama $\bar{a}^{c}$ gatherings, on which more shall follow in the next section. ${ }^{67}$ We find an anecdote in that regard from al-Fārūthī, who describes how his father took him to Umm 'Ubayda in $622 / 1225$ for the Rifāì festival, al-mawsim al-Aḥmadī, when he was eight years old: 68

A room in the convent (riwa $q$ ) was specially assigned for my father. Groups of people and lovers (muhibbün) had erected huts and tents

$67 \quad$ Note that in Islamic tradition the next day starts after the maghrib-prayer, which is in the evening, so that technically, the mawāsim started on Fridays. That is because, so al-Sāyyād also explains, a tradition of the Prophet relates that every Friday is a day of feast ( ${ }^{i} \bar{l} d$ ), cf. al-Ṣayyād, al-Ma'ārif al-Muḥammadìyya, p. 89.

Al-Fārūthī, Irshād al-muslimìn, p. 90. 
around Umm 'Ubayda so that the desert, the villages, and the fields became filled with pilgrims (zuwwār). On Friday they opened the noble mausoleum and tomb of Ahmad [al-Rifāīi], and thousands and thousands of people came to perform the visitation (ziyāra) ${ }^{69}$

While possibly an overestimation, Ibn Battetuta too claims that thousands of people were at the riwā $q$ when he went to Umm 'Ubayda to visit the mausoleum. ${ }^{70}$

We generally do not know exactly what the customs were when people visited the tomb of a pious man or woman in medieval Muslim societies. ${ }^{71}$ Nevertheless, several scholars have shown that it was not uncommon to implore the deceased individual to mediate with God, a practice referred to in Arabic by such terms as tawassul, wasilla, and istighātha. ${ }^{72}$ It is highly likely that the purpose of visiting al-Rifāī was to seek such mediation, and perhaps also that of his successors, all of whom were buried in the same mausoleum. ${ }^{73}$ That tawassul was practiced by the Rifāiss is corroborated by al-Ṣayyād, who gives a detailed account of the manner in which this ought to be performed. He explains that the faqir should be in a state of ritual purity, pray two cycles of prayer, praise the Prophet, and then turn himself to the direction of Umm 'Ubayda. He goes on to relate a lengthy prayer that should then be directed towards al-Rifāīi, which contains abundant lines of praise for the shaykh and ends with a plea for his help. ${ }^{74}$ We must bear in mind that al-Ṣayyād does not specifically connect this to the act of ziyāra, and that neither the other Rifā̄i authors nor alWāsitị make mention of anything of this sort. But the mere example of al-Ṣayyād's description of tawassul combined with the fact that we know of its existence as a custom in many different contexts of the Muslim world at that

\footnotetext{
69 Ibid. p. 91.

$70 \quad$ Ibn Batțūța, Rihla, vol. 2, p. 9.

71 Boaz Shoshan, Popular Culture in Medieval Cairo (New York: Cambridge University Press, 1993), p. 22.

72 For examples of scholars who discuss the ziyarra of tombs and seeking the intercession of pious individuals, see for the Mamluk context: Meri, The Cult of Saints, in particular chapter 3; and Christopher Schurman Taylor, In the Vicinity of the Righteous: Ziyāra and the Veneration of Muslim Saints in Late Medieval Egypt (Leiden: Brill, 1998), in particular chapter 4. See also Geoffroy, Le soufisme, p. 372; for an example of its existence in the context of Iraq, see for instance Makdisi, Ibn 'Aqil, pp. 209-212.

73 The line of succession of shaykhdom in the riwāq of Umm 'Ubayda consisted solely of descendants of al-Rifā̄ì all of whom were all buried there as well. Appendix 1 on p. 68-69 gives the line of shaykhs of the Rifāciyya up to the time of al-Fārūthì.

Al-Ṣayyād, al-Ma'ārif al-Muhammadiyya, pp. 112-114.
} 
time makes it plausible to assume that this was done by visitors of the Rifầ mausoleum as well.

\subsection{Rifā̄ic Practice: Samā' and Miracle-Working}

We have thus far seen that the shaykh, and in particular the $t \bar{a}$ 'ifa's founder, played a central role in the Rifāiyya: in life as the highest worldly and spiritual authority on earth, and after death as an object of ziyära and, presumptively, intercession as well. The fact that Rifā'ì sources substantiate much of al-Wāsițìs overall descriptions, be it directly or indirectly, shows that his outlook on the $t \bar{a}$ if $a$ can indeed be of historical value, albeit with due caution. With that in mind, we may now address the tă 'ifa's sama $\bar{a}^{c}$ gatherings and miracle-working, two intertwined central elements of Rifāè practice in which not only its shaykhs would have partaken, but also the generality of its followers.

The practice of $s a m \bar{a}^{c}$, which may be translated as 'audition' or 'spiritual concert,' is a ritual that is not easily defined due to its various manifestations. The Swiss scholar Fritz Meier rendered it as "musikhören," which he described as a session wherein Sufi poems are recited by singers, often accompanied by specific musical instruments, meant to bring about a rapture in listeners that arouses rhythmic movement which the Sufis call dancing (raqs). ${ }^{75}$ Although $s a m \bar{a}$ ' is not necessarily synonymous with the ritual of $d h i k r$, the remembrance of God, the two are connected with each other in the majority of the Sufi orders, as Meier also noted. When it comes to the early Rifā'iyya this was most likely the case as well. Our sources can be found referring to samā' and $d$ hikr interchangeably, which gives the impression that they were not necessarily differentiated from each other. ${ }^{76}$

Below we will continue reading al-Wāsițìs autobiography and focus on the way it illustrates how among the Rifāciyya a public samā' gathering could evolve into a spectacle of miraculous feats. Since it is, above all, al-Sayyād's manual that elaborates extensively upon this aspect of the țäifa in a section on the Rifāî̀ festival (mawsim), we shall use some of the details found therein to complement the account of al-Wāsiți in order to sketch a more complete image.

Our Iraqi Sufi commences by describing what a $s a m \bar{a}^{c}$ congregation in the Rifāiiyya looked like as he witnessed it during his youth. It would be made up of both men and women, among whom would be Rifāî̀ shaykhs, reciters and

75 Fritz Meier, "Der Derwischtanz: Versuch eines Überblicks," Asiatische Studien 8 (1954): pp. 122-124.

$7^{6}$ Ibid. pp. 133-135. Meier actually states that this is particularly the case for the Shādhiliyya, but also for many other Sufi groups, among which he also counts the later Rifāiiyya. For the distinction between dhikr and samăc, see also Geoffroy, Le Soufisme, pp. 407-408. 
singers of Sufi poems, and people holding banners. ${ }^{77}$ That banners were actually carried during such gatherings is confirmed by al-Ṣayyād, who identifies this as a characteristic custom of the order. According to his Sufi manual, this is based on the tradition of the Prophet's Companions who would carry banners during the lesser struggle (al-jihäd al-aṣghar) - the military campaigns to fight the enemies of Islam - and thus the fuqara $\bar{a}$ carry them during the greater struggle (al-jihād al-akbar) - the spiritual combat against the ego (nafs). ${ }^{78}$

The account of al-Wāsitị goes on to mention that upon reaching the location of the $s a m \bar{a}$, the women in the gathering would be placed in the vicinity around the circle of men, so that their faces could be seen in the background. ${ }^{79}$ This is very much problematized by al-Wāsitị, who recapitulates the issue of women in the țāifa several times in his autobiography. His main complaint in that regard revolves around the interaction between women and men, especially the shaykhs, which, in his view, poses a serious threat to Islamic morality. He adds that this also applies to the handsome young boy (al-șabi al-jamīl), whom he puts in the same category as women when it comes to the correct moral restrictions between sexes. While he gives examples of (intersexual) interaction among the Rifāīs that may not seem too serious, such as women and boys merely sleeping in the same house as the shaykh, or massaging his feet to obtain blessings, he also recounts instances where such contact had grave consequences, such as pregnancy from fornication $(z i n \bar{a}) .{ }^{80}$ As would be expected, we find nothing explicit about this in the works of our Rifāi authors. There is, however, a chapter in al-Fārūthī's Irshād that discusses some of the slander that was apparently directed at the ță iffa's founder. Here we do find an example of a complaint about al-Rifāi that reached the caliph of Baghdad in 550/1155: "they said [to the caliph] that he [al-Rifāis i] gathers men and women in the same circle (halqa) to remember God." ${ }^{81}$ Upon hearing this, the caliph sent someone to spy on their dhikr gatherings. When his servant returned, he reported that he had become deeply convinced that al-Rifāī actually holds fast to the Sunna, and that the complaints about him were false accusations, motivated by envy. ${ }^{82}$ Whether al-Wāsițīs allegations of fornication are true or not,

77 Al-Wāsițī, Riḥla, p. 19.

78 Al-Ṣayyād, al-Ma'ärif al-Muḥammadiyya, p. 89. This concept of the greater and the lesser jihād in Islamic tradition is based on a hadith, in which the Prophet is related to have made this distinction. For a study of this phenomenon, see for instance: David Cook, Understanding Jihad (Berkeley: University of California Press, 2005), chapter 2.

79 Al-Wāsițī, Riḥla, p. 19.

8 o Ibid. p. 21 and p. 23 .

81 Al-Fārūthī, Irshād al-muslimīn, p. 81.

82 Ibid. 
this shows that it was possibly customary for the țầifa to openly have women attending their dhikr gatherings together with men.

Besides mentioning that there would be music and dancing (raqṣ), al-Wāsițī discloses little more about the actual rituals of the $\operatorname{sam}_{\bar{a}}^{c} .^{83}$ Al-Ṣayyād, however, provides some details in that regard that may be of interest to us in order to understand the ța $\vec{a}^{\prime} i a^{\prime}$ 's theory behind it. The beating of drums (dufüf) that was common during the gatherings, for instance, is justified by him as a permissible act (mubāh $)$ according to the Shāfici school of jurisprudence. He explains that, according to the Sufis, this practice contains two deeper secrets: it brings about a state of happiness with God, and it raises the spiritual aspiration (himma) of the seeker. ${ }^{84}$ The actual raqș is something that al-Rifā'ì is said to have linked to the practice of a group of angels that dance and remember God under His Throne. Hence, the knowers of God dance during their remembrance as well. When they do so, their spirits (arwāhn) are with God and for God, which is contrasted with the hypocritical Sufi, who dances for himself and by himself. It is thus upon the faqir to dance with the spirit rather than the body, for when he truly remembers God, he will also be remembered by Him. ${ }^{85}$ That the $s a m \bar{a}^{c}$ and the raqș were not undisputed in scholarly circles is clear from the fact that al-Ṣayyād quotes from al-Rifāī that if your ecstasy (wajd) and your goal (qașd) are false, and you only remember God by the tongue, you will surely be like those whom the "veiled" jurists (al-fuqahä' al-mahjübūn) rightfully mock when they say "the fuqarä' dance!" 86

While the dance is certainly reprimanded by al-Wāsițī, it is the supposed supernatural abilities that the $s a m \bar{a}^{c}$ would generate in some of its participants that bother him the most. He gives a vivid example of this in the following passage:

When the $s a m \bar{a}$ ' is being performed, those among them who reach a state of bewilderment turn to snakes, which lay prepared in bags. They pull them out and gnaw on them out of their own free will (qaḍm al-khiyār), so that [the snake's] blood streams around the corners of their mouths.

83 Al-Wāsițī, Rị̣la, p. 17.

84 Al-Ṣayyād, al-Ma ārif al-Muḥammadìyya, p. 89.

85 Ibid. p. 82.

86 Ibid. p. 83. Note that the critical attitude of some jurists when it comes to $s a m \bar{a}^{c}$ and the raqs was by no means exclusively directed at the Rifāiyya, but at the practice in general. This was already the case in the time of the Malāmatī Sufi Abū 'Abd al-Raḥmān al-Sulamī (d. 412/1021), who wrote the earliest treatise in defense of $s a m \bar{a}^{`}$ and raqs, which attests to the existence of and debate about the ritual in his time already. On this, see: Kenneth Honerkamp, "Abū 'Abd al-Raḥmān al-Sulamī (d. 412/1201) on Samā', Ecstasy and Dance," JHS, 4 (2003): pp. 1-13. 
They subsequently blow this out over the people, claiming that it transforms to saffron and fruit in their mouths! I have seen among them someone who eats frogs, which he puts in his pockets before the $s a m \bar{a}^{c}$. Then, when the ritual is in process, he pulls one out and nibbles on it! There is no one who reproaches them for this, neither among our jurists, nor among our pious. Instead, we have come to view these innovations (bida $)$ as a well-known custom and an evident trademark [of the țăi ifa]. ${ }^{87}$

That such feats were actually performed by Sufis of the Rifấiyya is attested to in several other historical works from around the epoch that concerns us. A description that is very similar to al-Wāsițīs is found in the Rihla of Ibn Batțūtạ, who writes that he had witnessed how Rifā̄i fuqarā’ bit off snakes' heads and danced and rolled in fire during one of their sama $\bar{a}^{c}$ gatherings he attended. ${ }^{88}$ Earlier sources reveal a similar image. It is related from Sibṭ Ibn alJawzì (d. 654/1256) that the followers of al-Rifä'ì were known to ride on wild animals, play with snakes, and climb in palm trees to let themselves fall from a great height without feeling any pain. ${ }^{89}$ Because it is often cited by later Muslim historians, al-Rifầì's entry in the Wafayāt of Ibn Khallikān (d. 681/1282) is also noteworthy. He mentions that the shaykh's followers experience strange states $(a h w \bar{a} l)$, such as eating live snakes, walking through fire, and that it is said that they ride lions in their country. ${ }^{90}$ It can thus be concluded with some certainty that a kind of thaumaturgy indeed existed, at least in some instances of the $t \bar{a}$ iffa's practice of $s a m \bar{a}$.

It is, then, all the more surprising that of all the works by Rifāi shaykhs I examined, I only found al-Ṣayyād explicitly treating this subject. He actually describes miracle-working as an inherent part of Rifāīi rite. During the festivals (mawāsim), he explains, the fuqarä' may display manifestations of their elevated spiritual states, which occur due to the temporary suspension of natural laws (khawāriq). This ability emanates from the blessing (baraka) of al-Rifāī himself, he says, because all miraculous feats performed by his followers are graces that God bestows onto him. And since the charismatic powers of the

$87 \quad$ Al-Wāsiṭī, Riḥla, p. 19.

88 Ibn Batțūța, Riḥla, vol. 2, pp. 9-10.

89 As quoted by Muhammad b. Tahyāa al-Tādhifî (d. 963/1556) in Qalāìd al-jawāhir fì manāqib

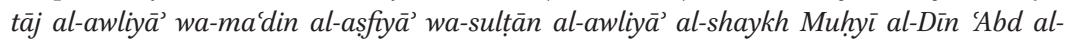
Qādir al-J̄̄lānī, ed. Aḥmad Farīd al-Mazīdī (Beirut: Dār al-kutub al-'ilmiyya, 2010), p. 314.

9o Shams al-Dīn Abū al-'Abbās Aḥmad Ibn Khallikān, Wafayāt al-a'yān wa-anbā' abnā’ alzamān. Ed. Iḥsān 'Abbās (Beirut: Dār al-șādir, 1968), vol. 1, p. 172; al-Dhahabī, for instance, copies this description in his Tārīkh, vol. 40, p. 255, as does 'Abd al-Hayy Ibn al-Imād alḤanbalī, Shadharāt al-dhahab fì akhbār man dhahab, ed. Maḥmūd al-Arnā’ūt (Damascus/ Beirut: Dār Ibn Kathīr, 1986), vol. 6, pp. 427-428. 
friends of God (karāmāt al-awliya $\bar{a}^{3}$ ) are in reality the miracles (mujizāt) of the Prophet Muhammad, they all have their precedent in Islamic tradition. Hence, al-Ṣayyād continues, being able to fall from a high place or enter a fire has its precedent in the Prophet Abraham, who was unaffected when he was thrown into a fire by Nimrod; drinking poison or recovering from injuries has its precedent in the Prophet Muhammad, who miraculously bore such tribulations; and riding lions has its precedent in 'Abd Allāh b. 'Umar, the Companion of the Prophet who was known to have pulled a lion by the ear to remove it from a road it was blocking. ${ }^{11}$ This shows that, at least from the point of view of the Rifāī branch of al-Ṣayyād, these practices were commonly accepted and that they were justified by connecting them to examples from Islamic tradition.

As we shall see in the next paragraph, there is reason to question the presence of such thaumaturgy in the earliest manifestation of the order. It is nonetheless probable that it had become something typical of their sam $\bar{a}^{\prime}$ gatherings by the time of al-Wāsitịis youth. This is confirmed by an anecdote of the latter's own shaykh in figh, al-Fārūthī, wherein he describes a samā'session he attended in the convent of Umm 'Ubayda. This was led by the last grandshaykh of the Rifāciyya he would live to see, Shams al-Dīn Muhammad b. 'Abd al-Rahīm alRifāì (d. 704/1305), whose reputation he says was well-known in Wāsiṭ. He then praises his miracle-working and recalls the following example:

He started a circle of remembrance (halqat al-dhikr) in the courtyard of the riwāq. As he reached a state of ecstasy, he pushed a column made of polished stone that was halfway in the ground. He removed it from its place with his hand after which he shattered it to pieces, [even though] this was something that twenty men would not be able to lift! ${ }^{92}$

It is interesting to note that this anecdote proves a point made by al-Wāsițī in his autobiography, namely, it was not only the common people who would attend such meetings of the Rifāiyya, but also reputable Muslim scholars. Men of knowledge, he argues, should actively fight such baseless innovations as

91 Al-Ṣayyād, al-Ma'ärif al-Muḥammadiyya, p. 9o. For this particular story of Abraham in Muslim tradition, see for instance Muhammad Ibn Jarīr al-Ṭabarī, The History of al-Tabarī. Volume II. Prophets and Patriarchs, trans. William M. Brinner (Albany, N.Y.: State University of New York Press, 1987), pp. 58-61. For the episode of Muhammad's poisoning, see again al-Ṭabarī, The History of al-Tabarī. Volume VIII. The Victory of Islam, trans. Michael Fishbein (Albany, N.Y.: State University of New York Press, 1997), pp. 123-124. For the story about 'Abd Allāh b. 'Umar confronting a lion, see for instance Kamāl al-Dīn Muḥammad b. Mūsā al-Damīrī, Hayāt al-ḥayawān al-kubrā (Beirut: Dār al-kutub al(ilmiyya, 2010), vol. 1, p. 11.

Al-Fārūthī, Irshād al-musliminn, p. 223. 
practiced by the Rifāiss. But instead they actually support and participate in them. Ironically, it is here that we find the only instance where he refers by name to the most distinguished teacher he had in Wāsiț:

The great hadith-scholars among their followers and adherents, such as 'Izz al-Dīn al-Fārūthī, attend their sama $\bar{a}^{`}$ gatherings. I [once] came to him when I was still an adolescent and said to him: "the Prophet (Ș) said that every newly invented thing is an innovation. Then what is the status of this samā?" It took him a while to answer me and this did not please him. The farthest his piety would extend to was to dislike having the $s a m \bar{a}^{c}$ in a mosque. But sometimes he [himself] attended it in the mosque, in covert dissimulation..$^{93}$ [ [personally] saw him in a mosque in which a $\operatorname{sam} \bar{a}^{c}$ was being held. So this is the state of the shaykhs and hadith-scholars? Now how can the Muhammaddan truth and the religion that separates truth from falsity exist among such people?! In fact, how can it be explained and taught, not to speak of spreading it and making it triumph?!94

\subsection{Depictions of the Rifā 'iyya: Antinomians or Mainstream Sufis?}

The common thread of al-Wāsiți’s autobiography has thus far led us through some of the Rifāiiyya's distinctive features he observed during his early years as an adolescent among them. He finishes his account with a conclusion that reiterates much of what we have already seen. He blames the Rifā'is for introducing the traveler on the Sufi path $(a l-s \bar{a} i r)$ to innovations such as relations with women and young boys, sleeping with them, grabbing live snakes, stepping into fire, and participating in $s a m \bar{a}^{c}$ gatherings. ${ }^{95}$ Such things exist among them, he argues, because the țäifa originated among shaykhs of the bațäih marshlands: "It is a fact that whenever city folk follow peasant shaykhs of the country (mashāyikh al-barr al-fallähinn), even if they are friends [of God] (awliy $\vec{a})$, their religion becomes corrupted and their state of affairs is altered. That is because idiocy (qillat al-aql) is evident among the countryfolk, and God did not sent a Prophet who belonged to them, nor to the desert Arabs!"96 The city folk's state of affairs, he continues, can therefore only be adjusted by following trained scholars ('ulamāo $) \cdot{ }^{97}$ In conclusion, he writes that he subsequently distanced himself from the Rifāiiyya in order to focus on the study of jurisprudence.

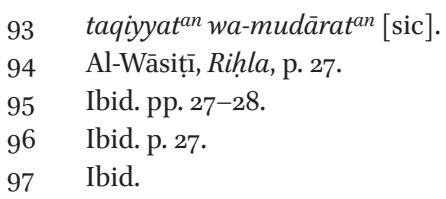


If we reflect on what drove al-Wāsiți's negative depiction of the Sufi order, it may be argued that this principally revolved around the way he came to delineate the proper boundaries of Sufism. This did not have to do with Sufism as such, as he clearly accepts it as an integral part of Islam. It was rather a matter of defining what constituted normative Sufism and what did not that gave rise to his critical views. As we have noted before, this was probably largely due to his individual study of Sufi manuals, which would soon be complemented by the study of God's commands and prohibitions when he turned to the jurists ( fuqahà) of Wāsit. As he explains in his autobiography, he then came to realize that there should be an equilibrium between the science of jurisprudence, the outward dimension of Islam, and the science of Sufism, the inward dimension of Islam. It was, in short, his realization that the Rifāiyya were lacking in their regard for the law that drove him to question their Sunni credentials.

When we consider the success of the țẳifa in Wāsiṭ and the marshlands, this raises important questions for our understanding of Sufism in the context of Ilkhanid southern Iraq. First, why does it appear from the sources that the Rifā̄īs were not widely contested by Wāsiț's Muslim scholars, whom one would assume to have functioned as the local custodians of Sunni normativity? Our study has already shown that the opposite was rather the case, namely, many Shāfici 1 fuqah $\bar{a}^{\prime}$ were themselves members of the Rifā'ì order and that it was apparently even difficult to express criticism about its practices. When elaborating on his study under the local jurists, we find al-Wāsițī confirming once more that he met fuqahä’ who were themselves members of the Rifā'iyya: "The remarkable thing is that I found among them some who firmly believe in this group [the Rifāiiyya] and who, in spite of their religious knowledge, call to the deviation of their way."98 If this was the case, and al-Wāsițîs critical attitude can thus be seen as an exception rather than the rule, could we then consider the Rifāiiyya as an example of what constituted normative Sufism in the context of seventh-/thirteenth-century Wāsit and its surroundings?

This does not appear to be the dominant view among scholars of Sufism, many of whom have portrayed the Rifāiiyya as a Sufi order that advocated extreme asceticism, and whose followers could occasionally be described as "heterodox" and "antinomian." In most instances, such depictions are probably based on the way the order is described by medieval Muslim historians, of which we have made note above. ${ }^{99}$ However, such an approach completely neglects the reception and position of the țăiff in its early Iraqi context.

98 Al-Wāsițī, Riḥla, p. 3 o.

99 See for instance: Denis Gril, "Esotérisme contre hérésie: 'Abd al-Rahmân al-Bistâmî, un représentant de la science des lettres à Bursa dans la première moitié du Xve siècle," in 
A few scholars have actually opted that the Rifāis is were probably more mainstream than some have made them out to be. Karamustafa has argued that, although their thaumaturgy may appear to clash with the scholastic norms of Muslim jurists, in general they do not seem to have deviated from social convention. Therefore, he says, they should not be counted among such world-renouncing Derwish groups as the Qalanders, the Haydaris, and the Abdāls of Rūm, whose radically ascetic, antinomian, and antisocial practices were the product of what he calls "deviant renunciation." Instead, he considers the Rifā'iyya order the product of "institutional Sufism," the scholastic Sufi tradition that revolved around mild asceticism and the cult of saints, and which gradually gave rise to well-organized brotherhoods. ${ }^{100}$ Reuven Amitai relies heavily on Karamustafa's two categories of deviant renunciation and institutional Sufism, and likewise rejects the assumption that the Rifāiyya were by definition Sufis of the antinomian kind. ${ }^{101}$ While both scholars thus bring a nuance to the biased depictions of the Rifầiss, their respective studies lack the textual evidence to support their shared thesis. It is here where our analysis of al-Wāsițī and the Rifāilyya may be of particular value and offer new insights into the țấifa's position in relation to its local trend of normative religiosity.

It is true that a certain method of renunciation, or zuhd, must have formed an integral part of the $t \bar{a} i f a$. However, it is difficult to establish with certainty how this was given form in their daily lives. Al-Fārūthī relates that the method (țarīq) of al-Rifāīi is characterized by lowliness (dhull), submission (inkisār), poverty (maskana), neediness (iftiqār), humility (khud̄uc), and helplessness (hayra), and that no other path to God will be greater and more difficult. ${ }^{102} \mathrm{We}$ find a similar set of terms to characterize the $t \bar{a}$ 'if $f$ 's method in the works of

Syncrétismes Et Hérésies Dans L'Orient Seljoukide Et Ottoman (XIVe-XVIIIe Siècles): Actes Du Colloque Du Collège De France, Octobre 20or, ed. Gilles Veinstein (Paris: Peeters, 2005), p. 191; Schimmel, Mystical Dimensions, pp. 248-249; David S. Margoliouth, "al-Rifā̄̄ī, Ahmad b. 'Ali," in $E I^{2}$ : vol. 8, pp. 524-525; J. Spencer Trimingham, The Sufi Orders in Islam (New York: Oxford University Press, 1998), pp. 37-40; Knysh, Islamic Mysticism, p. 210; Richard Gramlich, Die Wunder der Freunde Gottes: Theologien und Erscheinungsformen des islamischen Heiligenwunders (Stuttgart: Steiner Verlag Wiesbaden, 1987), pp. 229-300; Geoffroy, Le Soufisme, p. 210.

100 Karamustafa, God's Unruly Friends, pp. 55-56, and pp. 90-100.

101 Reuven Amitai uses this argument to prove that the conversion of the Mongols did not occur because antinomian Sufis had so many similarities with Shamanism. He convincingly shows that it were rather the moderate establishment mystics who contributed to spreading Islam among the Mongols, and he considers the Rifā̄is to be an example of this, see: "Sufis and Shamans: Some Remarks on the Islamization of the Mongols in the Ilkhanate," JESHO 42 (1999): pp. 38-40.

Al-Fārūthī, al-Nafha al-miskiyya, p. 10. 
al-Rāfi'ì, al-Ahmmadī, and al-Ṣayyād. ${ }^{103}$ This image of world-renunciation as the order's method is also confirmed in several biographical dictionaries of medieval authors who had no affiliation with the țäiffa. The Mamluk historians alSubkī and al-Dhahabī both cite an almost identical saying of al-Rifāìi in which he reportedly says: "I have not seen a shorter, easier, and more sound path [to God] than lowliness, neediness, and submission to the magnificence of God's command ..."104 While this suggests that it may have been a common notion that Rifāi i doctrine was built on renunciant ideals, this does not mean that the fuqara $\bar{a}$ were required to reject sharîa-law and cut themselves off from society. Indeed, al-Ahmadì quotes from al-Rifā'i that zuhd is not to eat badly or dress coarsely, but rather to rid your heart of this world. ${ }^{105}$ Several sources also give the impression that being in the service of the fuqara $\bar{a}$, physically and financially, and establishing a deep sense of altruism may have also been characteristic of Rifā'i renunciation. ${ }^{106}$ None of these elements seem to be of a particularly antinomian nature.

It may very well be that the ța iifa had a more sober approach to Sufism than some scholars have thought, at least in its earliest manifestation. This notion is only reinforced by the considerable effort all our Rifāi ì sources put into vouching for the Sunni credentials of their order's eponymous founder. On many occasions they can be found depicting the Rifāi order as the path of the Qur'an and the Sunna, and al-Rifāi $\overline{1}$ as the most knowledgeable scholar in that regard..$^{107}$ Al-Rifâ'î's spiritual routine is also portrayed as a sober set of practices, consisting of spiritual seclusion (khalwa), the frequent remembrance of God (dhikr), and sending prayers and blessings upon the Prophet. He would reportedly order his pupils to read the Qur'an often, perform supererogatory (nawäfil) and nightly prayers (qiy àm al-layl), and recite the țāiffa's litanies every day. He forbade excessive sleeping, eating, and being overly occupied with matters that

103 Al-Rāfi'ì, Sawād al-'aynayn, p. 19; al-Ahmadī, Ghanīmat al-farīqayn, p. 68; al-Ṣayyād, alMa'āif al-Muhammadiyya, p. 84.

104 Shams al-Dīn Muḥammad b. Aḥmad al-Dhahabī, Siyar a ‘ām al-nubalā’’ ed. Shu'ayb alArnā’ūṭ et al. (Mu’assasat al-risāla, 1985), vol. 21, p. 79; and very similar in al-Subkī, Țabaqāt al-shäficyya, vol. 6, p. 25 .

105 Al-Aḥmadī, Ghanimat al-farīqayn, p.66.

106 We have already seen al-Wāsițī characterizing the Rifāīi way thus above, when he describes his father. Ibn Fahd describes al-Fārūthī in a similar way: "He (R) possessed great altruism (ithār) - neither dirham nor dinar remained with him! I have been told that a merchant, known as Ibn al-Suwayqī, would send him a thousand dinars each year, but that he would be rid of it in the shortest time, spending it [all] before it was even obtained for the sake of the fuqarä' and the brethren." Cf. Ibn Fahd, Laḩ al-alhäz, p. 61.

107 Al-Rāfi'ì, Sawād al-'aynayn, p. 11 and p. 14; al-Ahmadī, Ghanimat al-farīqayn, p. 51, pp. 110111, and p. 125; al-Ṣayyād, al-Ma'ārif al-Muhammadiyya, p. 116. 
are allowed according to Islamic law (mubāhăt), something that shows he would have had a deep respect for the sharita. ${ }^{108}$ On the other hand, when confronted by an innovation (bid'a) or anything that contradicts the revealed law, they all describe al-Rifā̄i as a particularly harsh adversary. He is thus quoted in all our sources as refuting philosophy and the concepts of divine indwelling $(h u l \bar{u} l)$ or monism (ittihā $d)$. These things, he reportedly said, are a disease of the spiritual path because they threaten the affirmation of God's absolute unity (tawhìd), which is the cornerstone of faith. ${ }^{109}$ In matters of creed (itiqād) we even find al-Rifāī taking a somewhat traditionalist stance, where he is quoted as follows by al-Ṣayyād: "The people closest to heresy are the would-be Sufis (mutașawwifa) who are distracted from worshipping God by entering into discussions (kalām) about the divine essence (dhāt) and the divine attributes (șifāt)."110 In such matters, al-Ṣayyād claims, he preferred to abstain from any form of interpretation (tafsir $).{ }^{111}$

There is perhaps a certain irony in the fact that the image of al-Rifấi as a scholastic and sober Sufi shaykh is more or less confirmed by many medieval authors who could themselves at times be critical of the Sufi order. ${ }^{112}$ Even Ibn Taymiyya and al-Dhahabī, both of whom were particularly harsh towards contemporary Rifā'i Sufis, come to the defense of the order's eponymous founder. Al-Dhahabī holds that corruption only entered the țăi ifa after the Mongol conquest of Iraq, which gave birth to satanic states among its followers, such as entering fire, riding lions, and playing with snakes. He believed that the ță if $a^{\prime}$ s founder and the righteous among his followers are innocent of these matters. ${ }^{113}$ Ibn Taymiyya, too, acknowledges that many innovations only entered the Rifā' $\overline{1}$ order after the death of its founder. ${ }^{114}$ The Sufi biographer Jāmī expresses a

108 While mubāhāt are allowed, there is a carefulness in Islamic law with such matters, due to the fear that they may eventually lead to matters that are forbidden, cf. al-Fārūthī, Irshād al-muslimin, p. 102; al-Ahmadī, Ghanimat al-farīqayn, p. 6o.

109 Al-Rāfīì, Sawād al-'aynayn, p. 28; al-Ahmmadī, Ghanimat al-farīqayn, p. 49, pp. 94-95, and p. 135; al-Ṣayyād, al-Macāî al-Muhammadìya, p. 64; al-Fārūthī, Irshād al-muslimīn, pp. 100-101.

110 Al-Ṣayyād, al-Máāirif al-Muḥammadiyya, p. 3.

111 Ibid. pp. 4-5.

112 See for instance: Șalāḥ al-Dīn Khalīl al-Ṣafadī, al-Wâfí bi-al-wafayāt, ed. Ahmad al-Arnāūūt \& Turkī Mușțafā (Beirut: Ḍar ị̣yā̄ al-turāth, 200o), vol. 7, p. 143; Ibn Kathīr, al-Bidāya, vol. 12, p. 382; al-Subkī, Țabaqāt al-shāficiyya, vol. 2, p. 5; Ibn al-'Imād, Shadharāt, vol. 6, p. 427 .

113 Shams al-Dīn Muḥammad b. Aḥmad al-Dhahabī, al-Tbar fì khabar man ghabar, ed. Abū Hājar Muḥammad al-Sa'īd b. Basyūnī Zaghlūl (Beirut: Dār al-kutub al-'ilmiyya, 1985), vol. 3, p. 75 .

114 Ibn Taymiyya, $M F$, vol. 111, p. 494. 
similar opinion in his entry on al-Rifāīi. ${ }^{115}$ In that regard it is worthwhile adding that while our Rifāi ì sources certainly attribute several miracles to their grandshaykh, they never relate the kind of thaumaturgy that had apparently became customary during the order's sama $\bar{a}^{c}$ gatherings at the time of al-Wāsitị's youth. There may thus be some truth to the notion that such miracle-working as we have described above was only later incorporated into the tă $a f a$, though it remains impossible to say what may have caused this shift based on the current study. ${ }^{116}$ If this is indeed what happened, then it becomes all the more interesting that the incorporation of new practices into the Rifāiiyya apparently did not lead to much controversy in and around al-Wāsiț̣̄s hometown.

Whatever the case may be, our study here exemplifies how deeply notions of normative religiosity depend on context. If, as some scholars have seemingly done, we paint an image of the Rifāis on the basis of biased depictions of their medieval Muslim critics alone, this would indeed lead us to believe that we are dealing with a somewhat controversial Sufi order. However, by looking at the position of the Rifā̄is in their bastion of the Iraqi marshlands and Wāsit, one gets the impression that their practices apparently did not cross the boundaries of local conceptions of normativity. Comparing the works of our Rifā'i authors with al-Wāsițī's account of the ță $i f a$ has proven a useful tool in that regard. For in spite of al-Wāsitị̂s effort to explain in polemical terms how the Rifā'iyya deviated from his conception of normative Sufism, he has provided us with descriptions that have been of great value for our overall analysis of the order's position in its early local context. On the basis of our study of these sources we can conclude that Rifāì Sufism was in all likelihood generally regarded as perfectly normative in Wāsit and its surroundings, and could even be seen as the dominant trend of Sufism there.

Al-Wāsițīs Final Years in Iraq

While al-Wāsițī implies that it was essentially his frustration with the Rifāiyya that convinced him to leave Wāsit for good, a desire to seek knowledge with the jurists and Sufis of Baghdad may have also played a role. It must be noted that his autobiography never explicitly mentions that he actually migrated to the Iraqi capital, although it does contain a brief section on his involvement

115 Nūr al-Dīn 'Abd al-Rạ̣mān b. Aḥmad al-Jāmī, Nafaḥāt al-uns min ḥaḍarāt al-quds, ed. Muḥammad Adīb al-Jādir (Beirut: Dār al-kutub al-'ilmiyya, 2003), vol. 2, p. 709.

116 Geoffroy and Morgoliouth have both argued that thaumaturgy indeed entered the order later, perhaps one or two centuries after the death of its founder, Geoffroy, Le Soufisme, p. 210, and Margoliouth, "al-Rifä $\bar{\imath}$ " vol. 8, pp. 524-525. 
with a circle of Baghdadi Sufis. ${ }^{117}$ It is through the Hanbali biographer Ibn Rajab that we know he started studying Shāfi'i figh in Wāsiț, and then traveled to Baghdad to continue his studies under a group of Shāfi îs there. ${ }^{118}$ His description of the jurists he accompanied can therefore be taken as his general impression of them, and not as particular to Wāsit or Baghdad. In the following pages we will continue with a study of his account of them and the Baghdadi Sufi circle he joined.

\subsection{The Sober Shäfí Iurists}

In al-Wāsițī's days, his native town was still a metropolis of some repute in the field of Muslim learning. Its scholars were especially known as masters of qira'ät, the different styles of Qur'anic recitation. ${ }^{119}$ As in the rest of Iraq, the majority of Wāsiț's jurists were probably Sunnis who followed either the Shāfi'i or the Ḥanafì school. The Hanbalī school, which al-Wāsițī would switch to upon settling in Damascus, may also have had some following. Since the death of its founder, Ahmad Ibn Hanbal (d. 241/855), Baghdad had been the capital of Hanbalism, but the Mongol conquest had struck a severe blow to its overall influence in Iraq. ${ }^{120}$ In theology, the Ash'arī school appears to have been widely represented and, albeit to a limited degree, facilitated philosophical discussions within their formulation of normative Sunni theology. ${ }^{121}$ The Shi'ites were still very much a minority group in this context.

Because al-Wāsițī's father was a Shāfi'ì, it was only natural that he followed the same madhhab. Of the several madrasas known to have existed in Wāsit, there was one dedicated solely to Shäfi'i figh in the city's east, which may very

\footnotetext{
117 Al-Wāsițī, Rị̣la, p. 31.

118 Ibn Rajab, Dhayl, vol. 4, p. 381.

119 Bosworth, "Wāsiț," pp. 8o-81.

120 The Shāfīi and Ḥanafì madhhab were already the dominant schools in Iraq during the Seljuq period, and continued to be so in the century that followed. The Ilkhan Oljeitü (r. 703-716/1304-1316) was known to support them until he became tired of the constant arguments between adherents of the two schools, cf. Bausani, "Religion under the Mongols," pp. 543-544. Since the death of its founder, Ahmad Ibn Hanbal, Baghdad had been the main center of Hanbalism. Thanks to the pro-Sunni policy, the school's influence thrived under the last caliphs of the Iraqi capital, but collapsed after it was conquered by the Mongols, cf. Laoust, "Le Hanbalisme," pp. 116-121. Bosworth remarks that Wāsiṭ was a "predominantly Sunni city, with a strong Ḥanbalī element in it," cf. Bosworth, "Wāsiț," p. 85, and see also: Alessandro Bausani, "Religion in the Saljuq Period," in cHIr v: pp. $283-284$. While it is difficult to judge in how far this was really the case, we do find several examples of Ḥanbalīs who traveled to Wāsit to study Qur'anic recitation, see: Ibn Rajab, Dhayl, vol. 3, p. 126, p. 362, and p. 55o, and vol. 4, p. 21.

121 Hodgson, The Venture of Islam, Volume 2, p. 323; Bausani, "Religion in the Saljuq Period," p. 285 .
} 
well have been attended by al-Wāsițī when he decided to study jurisprudence. ${ }^{122}$ It is difficult to say exactly how far he delved into the discipline. He does relate a list of the most prominent books from which his masters would quote when discussing fiqh-issues (sing. mas'ala, pl. masä'il), which may indicate that he reached a certain degree of proficiency in the Shāfi'i tradition. He names alTanbīh and al-Muhadhdhab, both by Abū Isḥāq Ibrāhīm al-Shirāzī (d. 476/1083), al-Wajīz and al-Wasịt, both by Abū Hāmid al-Ghazālī (d. 505/1111), al-'Azìz fì sharh al-wajiz, al-H̄āwì al-ṣaghīr, al-Lubāb, and al-'Ujāb fisharh al-lubāb, all by Najm al-Dīn 'Abd al-Ghaffār al-Qazwīnī (d. 665/1266), and al-Muharrar, by alRāfi $\overline{1}$, whom we have already come across as a member of the Rifā'iyya. ${ }^{123} \mathrm{Sev}-$ eral classical sources confirm that these works were indeed considered by many as some of the most celebrated figh-books in the madhhab around the period that concerns us. ${ }^{124} \mathrm{Al}-\mathrm{Wa}$ àiți states in his autobiography that he mainly devoted himself to jurisprudence because he had become convinced of the necessity of having intimate knowledge of God's laws. After all, so he tells us, it is thereby that one knows which deeds lead to God's reward and which deeds lead to His punishment. As he saw it, his switch to figh was "a light and a guide during dark times."125

But while he was initially pleased to be among a class of Muslims he considered superior to the Rifā'īs, he soon found himself disappointed once more due to their sole occupation with jurisprudence. His statement that "they are only concerned with fiqh, nothing else"126 in all likelihood alludes to their lack of concern for the inward dimension of Islam, that is, Sufism. He also hints at this in his Talqịh al-afhām, where he states that many righteous jurists may reach

122 This was Madrasat al-Barrāniyya; in his study on the schools of Wāsiț, Nājī Ma'rūf mentions that he found three different names of Shāfīi madrasas in the city: al-Madrasa al-Barrāniyya, Madrasat Khațlaburs, and al-Madrasa al-Sharābiyya. He argues that these were not three separate schools, but rather one and the same madrasa, whose name changed several times over the years. Cf. Nājī Ma'rūf, Madāris Wāsiṭ (Baghdad: Mațba't al-irshād, 1966), pp. 16-17. I have found very little about these schools, besides the mention of one Yahyyā b. 'Abd Allāh Abū Zakariyyā al-Wāsiṭī (d. 738/1337) who apparently studied under al-Fārūthī and later became a teacher at the Barrāniyya; see al-Subkī, Ṭabaqāt alshäfíiyya, vol. o1, p. 391. Al-Wāsițī, Riḥla, p. 29.

Al-Tanbīh, al-Muhadhdhab, al-Wajizz, and al-Wasiț, are mentioned by celebrated Shāficì jurist al-Nawawī (d. 676/1277) as the greatest masterpieces of Shāfíi jurisprudence, cf. Muḥyī al-Dīn Yaḥyā al-Nawawī, Tahdhīb al-asmā’ wa-al-lughāt (Beirut: Dār al-kutub al'ilmiyya, 1977), vol. 1, p. 3. 'Abd al-Ghaffār al-Qazwīnī was also an important authority in the madhhab, whose Hīwwi in particular was famed; see for instance: al-Subkī, Tabaqāt al-shāfíiyya, vol. 8, pp. 277-278; al-Dhahabī, Tārīkh, vol. 49, pp. 197-198; Yāfi'ī, Mir'āt, vol. 4, pp. 126-127. For al-Rāfiè's book, see al-Subkī, Tabaqāt al-shāficiyya, vol. 8, p. 281. 
outward steadfastness (istiqāma) but taste nothing of the works of the heart. Some of them, he adds, may even reject the inner-path altogether, thinking that all things beyond their outward knowledge are innovations (bida $\left.{ }^{\text {can }}\right) .{ }^{127}$ He thus concludes that, just as the Rifā̄is were lacking in figh, the jurists were lacking in tasawwuf, so that the latter too did not offer him the religious balance he sought: "I remained with them for a period of time, being confined like a bird in a cage, only getting a breath of fresh air from the books of the Sufis!"128

Another aspect of the jurists' approach to religion he claims to have been critical of is their deep knowledge of figh-discussions, while neglecting the actual sources on which these are based, namely, the Qur'an and the Sunna. However, as with all the opinions he formulates in his autobiography, we must heed the possibility that he may have been projecting back on the past opinions that he only came to hold later on in his life as a Hanbali convert. As this could very well be the case here, we may assume that it was, above all, his desire for a balanced inward and outward experience of religion that was at the heart of his growing unease with the jurists.

The same goes for his supposed critical attitude towards their acceptance of ilm al-kalām as a legitimate Islamic science. Here too we are dealing with an opinion he probably held later on in his life after having been exposed to proponents of traditionalist theology, but not yet as a student of jurisprudence in Wāsiț. For although he seemingly shies away from admitting any direct affiliation with Ash'arism in his autobiography, he would surely have been exposed to the school's teachings there. It is, for instance, doubtful that he would not have studied any basic text of Ash'arī kalām with some of his shaykhs in figh. Most of them, if not all, ascribed to Ash'arism when it came to creed. This is evidently implied in his autobiography where he states that he found them particularly fond of Fakhr al-Dīn al-Rāzì (d. 606/1209), the celebrated Shāfíi Ash'arī theologian:

Among them are those who combine [the study of] the principles of jurisprudence (ușül al-figh) with the specialized vocabulary (iștilāhh) of [Fakhr al-Dīn] Ibn al-Khațîb [al-Rāzī], while venerating and magnifying him, affirming that he is the greatest Imam and one of the pillars of this religion. ${ }^{129}$

As for his own exposure to Ash'arism among the Shāfi'is, there is a short theological tract that he probably wrote in Damascus shortly before switching to 
the Hanbali school, wherein he hints at this. In it he explains that he reached a point where he was greatly confused about the theological doctrines that opt for a metaphorical interpretation of the divine attributes (șifāt) that are mentioned in the holy texts:

Among those who believe in these doctrines $(a q w \bar{a} l)$, or in some of them, there are people who have a standing in my heart, such as a group of the Shāfi'i jurists from among the Ash'arīs. That is because I follow the school of al-Shāfi'i $(\mathrm{R})$ and I learned the obligations and rulings of my religion [from them]. I found the likes of these venerable shaykhs believing in these kind of doctrines. But they were my shaykhs and I had complete faith in them due to their erudition and knowledge. ${ }^{130}$

So even though he would come to denounce the Ash'arīs completely, especially when he turned to Hanbalism, the above quote seems to suggest that, initially, he did not question their doctrine. This was simply what was being taught by his shaykhs, whom he clearly held in high regard, and for most of whom being Shāfí̄ and Ash'arī would have gone hand in hand. It is thus all the more likely that al-Wāsiți followed this example when he was still a young student.

\subsection{The Baghdadi Sufis}

As he felt increasingly discontent with what the jurists had to offer him in terms of religiosity, his switch to Baghdad may have felt as an opening to new prospects for his intellectual and spiritual hunger. From Wāsit it was an eightday journey to the capital of Iraq, which would have offered many opportunities to seek knowledge among the scholars and Sufis that the city housed so abundantly. ${ }^{131}$

It is here where al-Wāsiți entered a master-disciple relationship (șuḥba) amidst the aforementioned Sufis he calls muțāwi'at al-baghādida, which we may render as 'obedient followers of the Baghdadi Sufis.' This title likely indicates that they ascribed to the Baghdad school of Sufism. ${ }^{132}$ Although not ex-

130 Al-Wāsițī, Risāla fù ithbāt, p. 26.

131 Vasilii Vladimirovich Bartold, An historical geography of Iran, tr. Svat Soucek, ed. C. Edmund Bosworth (Princeton, N.J. : Princeton University Press, 1984), p. 203.

132 Al-Wāsiți, Rịhla, p. 31. For an explanation of the concept of șụ̣ba, see: Ohlander, Sufism, p. 28. Also note that I am aware that there did exist a Sufi order that was known by the name 'Muțāwi'a.' However, it is very unlikely that this is what al-Wāsițī is referring to, since this particular order was known to have flourished only between the fifteenth and eighteenth centuries in Egypt, as a branch of Ahmad al-Badawì's (d. 675/1276) Ahmmadiyya. They also appear to have been highly controversial, which does not exactly concur with the way al-Wāsițī describes them. On this Muțāwi'a, see for instance: Khaled El-Rouayheb, 
plicitly stated as such in his autobiography, we find proof for this in $Q \bar{a}$ ida $f_{\imath}$ așnāfal-ta'alluh, another short work of al-Wāsițī with several autobiographical passages:

The first path that I entered was the path of Sufism (tașawwuf) according to the spiritual presence of Sufis (rūhanniyyat al-șüfiyya) such as Junayd, Abū Sa īd al-Kharrāz, and their contemporaries. This was after [I had taken] the path of jurisprudence (figh) according to the school of al-Shāfi'ì, by which the details of the religious obligations and the Sunna are known. ${ }^{133}$

Here, he describes the branch of Sufism he became involved with after his study of jurisprudence as the path of Junayd (d. 289/910) and al-Kharrāz (d. ca. 286/899), two of the foremost representatives of the Baghdad school of Sufism. ${ }^{134}$ The word 'baghädida' in his autobiography is therefore very likely meant as a reference to those Sufi masters who represented this school. We may then assume that, although al-Wāsiți does not link the Sufis he accompanied in Baghdad to any particular țâi ifa, they likely identified themselves as belonging to this tradition.

Because al-Wāsiți presents us with very little information about them it is practically impossible to find additional material that may help us identify them. There is but one clue in his autobiography that tells us something more about their background, which is where he describes that

they venerate the [Sufi] shaykhs (al-mashāyikh), though not like the first group [i.e. the Rifāiiyya]. Nevertheless, there is among them a branch of that kind, who uncover their heads at the mausoleum of Ibn Idrīs and kiss its threshold - and I did this with them when I was a young man although they do not fall into the same filthy deeds [that the Rifāiyya do]..$^{135}$

Without doubt, the Ibn Idrīs mentioned here is Abū al-Ḥasan 'Alī Ibn Idrīs alRawḥā'ī al-Ba'qūbī (d. 619/1222) - sometimes misspelled as al-Ya'qūbī - a direct

"Heresy and Sufism in the Arabic-Islamic world, 1550-1750: Some preliminary observations," BSOAS, 73, (2010): pp. 361-362; Michael Winter, Society and religion in early Ottoman Egypt: studies in the writings of 'Abd al-Wahhāb al-Sha'rānì (New Brunswick N.J. etc.: Transaction Books, 1982), p. 104; Geoffroy, Le soufisme, p. 206. Al-Wāsițī, Qã̄ida fí aṣnāf al-tảalluh, p. 149.

134 For the Baghdad school of Sufism, see: Karamustafa, Sufism, on Junayd, p. 18, on al-Kharrāz, pp. 7-10.

135 Al-Wāsițī, Rihlala, p. 32. 
pupil of two renowned Baghdadi Sufi masters, the Hanbalī shaykh 'Abd alQādir al-Jīlānī (d. 561/1166), and the lesser-known shaykh 'Alī al-Hìtī (d. 564/1169). Now, Ibn Idrīs had a Sufi convent (ribāt t) in a village called Rawḥā', near the city Ba'qūba, which is a day's journey from Baghdad. As attested to in several historical sources, he was buried there in a mausoleum that was erected in his convent, and indeed became an object of ziyāra. ${ }^{136}$ The fact that alWāsiți only mentions his name in the section on the Baghdadi Sufis may be taken as an indication that they were affiliated with his silsila.

Nevertheless, this still leaves us with very little on the possible background of these Sufis. There is hardly anything to be found concerning the Sufi doctrine and legacy of Ibn Idrīs, let alone anything that points to a particular tă if that followed from his teachings. Since al-jīlānì was one of his masters in Sufism, it is very well possible that he was in some way at the outset of what could be identified as the earliest manifestation of the Qādiriyya order. Such a suggestion must be treated with great caution, however, since our knowledge of the early țẳifa is very scant. Al-Jīlānī himself may even have had little or nothing to do with its actual formation, and much of what would later be attributed to the Hanbalī shaykh was likely quite far from his actual teachings. ${ }^{137}$ It is of-

136 See: al-Dhahabī, Siyar, vol. 22, pp. 177-178; al-Dhahabī, Tārīkh, vol. 44, pp. 455-456; al-Tādhifì, Qalā’id, pp. 381-382; and for other references, see 'Umar Salīm 'Abd al-Q̨ādir Tall's study of Sufis in twelfth-century Baghdad: Mutașawwifat Baghdād:fíal-qarn al-sādis al-hïrī/al-thānī 'ashar al-mülādī: dirāsa tārīkhiyya (Amman: Dār al-ma'mūn li-al-nashr wa-al-tawzī', 2009), p. 148.

137 Much work remains to be done when it comes to the critical study of al-Jīlānì's teachings and Sufi order. Jacqueline Chabbi has perhaps been most critical when it comes to alJilānī's role as a Sufi shaykh. She argues that the Hanbali master should be viewed as the patron and not the founder of the Qādiriyya. She even goes as far as to state that al-Jīlānī ran a madrasa rather than a ribāt, and that his success was not due to his brilliance in the field of mysticism, but due to his ability to preach $(w a z)$, which is how fame was acquired in his times, so she argues. She concludes that he should therefore be seen as a man of his age who made good use of the opportunities that he found around him; see: "Abd alKâdir al-Djilânî, personnage historique," StI 38 (1973): in particular p. 76, and pp. 100-101. Some of the clearest cases where we find al-Jilānì's name connected to teachings that were not his own are the several books that are incorrectly attributed to him. Ibn Rajab only mentions al-Ghunya and Futūh al-ghayb as his authentic works (cf. Ibn Rajab's Dhayl, vol. 1 p. 248), and most other titles are likely dubious. Examples of inauthentic works are a tafsìr attributed to him, which contains explanations of God's attributes that contradict the traditionalist position, cf. al-jīlānī, Tafsìr al-jūlānī, ed. Aḥmad Farīd alMizyadī (Beirut: Beirut: Dār al-kutub al-ilmiyya, 2009), see for instance vol. 3, pp. 138-140, where God's sitting on the Throne (istiwa $\bar{a}^{\prime}$ ) is interpreted as His dominion (istilla $\left.\vec{a}^{\prime}\right)$, and vol. 2, p. 304 where the eye of God ('ayn) is interpreted as God's guard, proximity, or safekeeping. The same goes for the book Sirr al-asrār wa mažhar al-anwār (Dihlī: Kutubkhāna Ishā'at al-Islām, 1985), on pp. 81-83, where we find that only the Ḥanafĩ and Shāfi î position with regard to special prayers are mentioned, and not the Hanbalī. That the fabulous tales attributed to the shaykh soon after his passing were not on the whole 
ten overlooked that al-Jilānī was in fact a true traditionalist in creed, and was considered the shaykh of the Hanbaliss in his time. Nonetheless, there is no reason to doubt Ibn Idrīs' șuḥba-relationship with al-Jīlānī, especially in consideration of his apparent Hanbalī leanings. Both Ibn Taymiyya and Ibn Rajab relate that Ibn Idrīs once asked al-Jīlānī whether there has ever been a friend of God (wali $)$ who followed a creed other than that of Ahmad Ibn Hanbal, to which the shaykh replied: "there never was, and there never will."138 It can hardly be a coincidence that the most distinguished pupils of Ibn Idris mentioned in the biographical sources were Hanbalīs from Baghdad. The fact that they all transmitted hadith from him as well only adds to his apparent appreciation for traditionalism. ${ }^{139}$ Among these pupils we find the Hanbali Sufis Abū Zakariyyā Yahyyā al-Ṣarșarī and 'Alī b. Sulaymān al-Khabbāz, both killed in 656/1258 fighting the Mongols from the latter's convent (zāwiya) in Baghdad. The Ḥanbalī jurist Kamāl al-Dīn 'Alī Ibn Waḍḍāh al-Shahrābābī (d. 672/1273), who was a friend of al-Ṣarșarī, also received the khirqa from Ibn Idrīs, but does not appear to have initiated disciples himself. ${ }^{140}$ Unfortunately, there is no way to uncover how the legacy of Ibn Idrīs' Sufi circle continued beyond the lives of these Hanbalīs.

undisputed is evident from Ibn Taymiyya and al-Dhahabī, both of whom clearly respected al-Jīlānī but were troubled by the legends that were erected around his persona; see: Ibn Taymiyya, Bughyat al-murtād fíal-radd 'alā al-mutafalsifa wa-al-Qarāmița wa-al-Bātininiyya ahl al-ilhāad min al-qā̉ilīn bi-al-ḥulūl wa-al-ittihâad, ed. Mūsā b. Sulaymān Duwaysh (Medina: Maktabat al-'ulūm wa-al-hiikam, 1995), p. 493, and al-Dhahabī, Tärīkh, vol. 39, p. 100.

138 Ibn Rajab, Dhayl, vol. 2, p. 20o. Ibn Taymiyya, Dar'ta'ārud al-'aql wa-al-naql, ed. Muhammad Rashād Sālim (Riyad: Jāmi‘at al-imām Muhammad b. Sacūd al-islāmiyya, 1991), vol. 5, p. 5, and also in his Kitāb al-istiqāma, ed. Muḥammad Rashād Sālim (Riyad: Jāmi‘at alimām Muḥammad b. Sacūd al-Islāmiyya, 1983), vol. 1, p. 85. That al-Jīlānī was a staunch advocate of the traditionalist creed is clear from the section on the divine attributes in his Ghunya, where he also dismisses 'ilm al-kalām and Ash'arism, see: al-Jīlānī, al-Ghunya lițālibì țarīq al-haqq 'azza wa jalla ( fì al-akhlāq wa-al-tașawwuf wa-al-adāb al-islāmiyya), ed. Abū 'Abd al-Raḥmān Șalāḥ b. Muḥammad Ibn 'Uwayḍa (Beirut: Dār al-kutub al-ilmiyya, 2007), vol. 1, pp. 121-127. It also appears to be hinted at in al-Fath al-rabbānī, a collection of discourses by al-jīlānī that was compiled by students, where we find the following quote from the shaykh: "the Lord is upon the Throne, as He said, with no question of anthropomorphism (tashbih), the negation of attributes (tat țil) or ascribing bodily form (tajsīm)." See: al-Fath al-Rabbānī wa-al-fayḍ al-raḥmānī. (Cairo: al-Maktaba al-azhariyya li-al-turāth, 2008), p. 86. On al-Jīlāni’s traditionalist theology, see also: Malik, The Grey Falcon, chapter 4.

139 For his role as a teacher of hadith, see for instance: Ibn Rajab, Dhayl, vol. 4, p. 32, p. 38, and p. 111.

140 For al-Ṣarșarī and al-Khabbāz, see Ibn Rajab, Dhayl, vol. 4, pp. 31-39. On Ibn Waḍḍāḥ, see Ibn Rajab, Dhayl, vol. 4, p. 111, and al-Dhahabī, Tārīkh, vol. 5o, pp. 102-103. 
We are thus completely at the mercy of al-Wāsițīs autobiography for our image of the Sufis he accompanied in Baghdad. Based on the above, we can only say that it is possible that he came in contact with adherents of the traditionalist creed in Baghdad - which, we should not forget, had since long been the Hanbali capital - although he makes no mention of this anywhere. If this was indeed the case, he may (as he himself seems to claim) already have started to move away from Ash'arism in favor of traditionalism before migrating from Iraq.

Like with the Shāfi'ìs, al-Wāsițī's autobiography tells us that he was initially relieved to have found an approach to religion that seemed to quench his spiritual and intellectual thirst. He states that the Baghdadi Sufis were "a thousand times better than the previous two groups," for he found them upholding a much greater degree of balance in their religiosity. They pursued the Sufi path while being simultaneously conscious of God's law by adhering to the juristic schools (madhāhib al-fuqahä'). ${ }^{141}$ In his Qāंida fi așnāf al-ta'alluh, he provides some additional details about their approach to Sufism. He states that, unlike the jurists, they realize that the Muhammadan $\operatorname{sharit}^{-} a$ is useful for the masses ('awāmm) but that it is not enough to satisfy the burning desire (ihtirāq) of someone who truly seeks God. He expounds that their method is aimed at disciplining oneself through such practices as nightly vigilance, hunger, poverty, and relying only on God for one's provision. That way, he says, one can attain something of the traces of divine proximity (qurb), which manifest through the perception of certain attributes of God (sifāt). ${ }^{142}$

In spite of this, al-Wāsiți eventually became disappointed once more because of certain deviant traits (al-akhlāq al-munharifa) he claims to have perceived among them. Although their spiritual way may certainly lead to witnessing something of the Divine (shuhūd), he says, it is still cut off from the most complete spiritual reality he calls 'al-amr al-kulli.'143 He elaborates on what these deviant traits are in his autobiography, where he describes them as a people who wear patched Sufi cloaks (ahl dalūq wa-muraqqa'ātwa-sharāshị riq $\bar{a}^{c}$ ), hinting at their seemingly renunciant lifestyle, while in practice being mostly occupied with worldly desires (shahawāt), such as good food, befriending the rich, and obtaining donations from them. Like the Rifāciyya, he criticizes them for wasting their servitude of God ('ubüdiyya) with samā' gatherings, during which they skillfully dance but taste nothing of the Divine. ${ }^{144}$ It is worth nothing that, although there is little more to substantiate the possible link be-

\footnotetext{
141 Al-Wāsițī, Riḥla, p. 31.

142 Al-Wāsițī, Qā'ida fı́ aṣnāf al-ta’alluh, p. 15 o.

143 Ibid.

144 Al-Wāsițī, Riḥla, pp. 31-32.
} 
tween these Sufis and Ibn Idrīs, the latter's circle is known to have held sama $\bar{a}^{c}$ gatherings as well. ${ }^{145}$

The gist of his critique is that he found them striving to appear as Sufis, while not truly aspiring for the goal of the Sufi path, which is to reach a profound connection with God. In other words, he found that the means have become the ends in their practice of the science of tasawwuf. Now, it is unlikely that he had already formulated the borders of what constitutes traditionalist Sufism as he would come to do in Damascus. So just as with the Rifāiiyya, his critiques appear to have emerged from his own knowledge and understanding of Sufism which he took from the Sufi manuals he studied:

No one [among them] speaks of seeking arrival [unto God] (wușūl) at all, for this is a discipline that has diminished.... I associated with them, but their state did not please me. I knew through my instinct that the matter [I pursued] is superior to this, and I would only get a breath of fresh air from the books of the Sufis. ${ }^{146}$

Upon closing his account of Iraq, al-Wāsiți concludes that, looking back on his experiences thus far, he found all the groups he accompanied falling short in traveling the path unto God. People were either only focused on worship with no knowledge of God's law, on jurisprudence with no knowledge of the spiritual path, or on following a Sufi tradition without actually fulfilling its purpose.

But God (T) put intimate knowledge of Him (ma'rifa) and nearness to Him (qurb) in my heart, so that it became enraptured. I did not know the reality of what befell my heart, and could not find anyone who could guide me to what I was seeking, acquaint me with my medicine, or explain to me what this passionate love (haymān) was that befell me. Thus I remained bewildered and confused, unable to find stability, while my heart became depressed from all the groups that I accompanied and associated with. ${ }^{147}$

This, he tells us, occurred around the year 683/1284, when he must have been about twenty-six years old. It finally convinced him to leave Iraq in search of something better. He would never again return.

\footnotetext{
145 That Ibn Idrīs partook in samā' gatherings is hinted at in Ibn Rajab's Dhayl, vol. 3, p. 445. Ibn Rajab explicitly mentions that Ibn Idrīs' disciple, al-Ṣarșarī, did attend sama $\bar{a}^{c}$ gatherings in Dhayl, vol. 4, p. 34 .

146 Al-Wāsițī, Rị̣la, p. 32.

147 Ibid. p. 33 .
} 


\section{Appendix 1: The Line of Rifā̄̄ Shaykhs in Umm 'Ubayda and Wāsit}

\section{Umm 'Ubayda}

Aḥmad Abū al-'Abbās

al-Rifāàì (d. 578/1182)<smiles>C1CCCC1</smiles>

Sayf al-Dīn 'Alī b. 'Uthmān

al-Rifāī (d. 584/1188) $)^{149}$

Mumahhid al-Dīn 'Abd al-Rahīm

b. 'Uthmān al-Rifā̄ī (d. 6o4/1208) ${ }^{150}$<smiles>[Li][Ca]</smiles>

Muḥ̂̄i al-Dīn Abū Isḥāq Ibrāhīm al-A`zab al-Rifā̄ī (d. 6og/1212) $)^{151}$

\section{Wāsit}

'Izz al-Dīn Abū al-Faraj 'Umar b. Aḥmad al-Fārūthī al-Wāsițī (d. 585/1189) ${ }^{148}$

Muhỵī al-Dīn Abū Isḥāq

Ibrāhīm al-Fārūthī al-Wāsițī

\section{Shams al-Dīn Muhammad b. 'Abd}

'Izz al-Dīn Aḥmad b. Ibrāhīm

al-Rahīm al-Rifā̄ì (d. 629/1232) $)^{152}$ al-Fārūthī (d. 694/1295)

Abū al-Ḥasan 'Alī (nicknamed 'Abd

al-Muḥsin) al-Rifāī (d. 63o/1233)153

Quṭb al-Dīn Abū al-Ḥasan 'Alī b.

'Abd al-Rahīm al-Rifāc̄̄ (d. 636/1238)'154

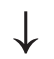

Najm al-Dīn Aḥmad b. 'Alī

al-Rifā̄ì (d. 645/1247) $)^{155}$

148 According to al-Fārūthī, his grandfather was granted the leadership of outward knowledge and the spiritual path in Wāsiț, cf. Irshād al-muslimīn, p. 236.

149 Aḥmad al-Rifāīì was his maternal uncle, ibid. p. 188.

150 The brother of his predecessor, Sayf al-Dīn, ibid. p. 191.

151 A Grandson of al-Rifācīi, ibid. pp. 194-195.

152 His predecessor, Muḥȳ al-Dīn, was his maternal uncle, ibid. p. 211.

153 The brother of his predecessor, Shams al-Dīn, ibid. p. 213.

154 Another brother to his predecessor, Ibid. p. 218.

155 Ibid. p. 220. 
$\downarrow$

Quṭb al-Dīn Aḥmad b. Shams al-Dīn

Muhammad al-Rifā̄ī (d. 670/1272) 156<smiles>[CH][AlH]</smiles>

Shams al-Dīn Muhạmmad b. 'Abd

al-Raḥīm al-Rifāīì (d. 704/1305) $)^{157}$

156 Ibid. p. 222.

157 He is the last successor mentioned by al-Fārūthī, ibid. p. 223 . 